$\begin{array}{cc}\text { Türk Coğrafya Dergisi } & \text { Turkish Geographical Review } \\ \text { Basılı ISSN 1302-5856 } & \text { www.tcd.org.tr }\end{array}$

\title{
Arkeolojik yerleşim yerleri ile jeomorfoloji arasındaki etkileşim: Aşağı Garzan Havzası örneği ${ }^{1}$
}

\section{Interaction between archaeological site and geomorphology: a case study of the Lower Garzan Basin $^{2}$}

\author{
Savaş Sarıaltun ${ }^{{ }^{*}}$ \\ a Çanakkale Onsekiz Mart Üniversitesi, Sosyal Bilimler Enstitüsü, Çanakkale, Türkiye.
}

ORCID: S.S. 0000-0003-4190-3727

\begin{tabular}{|c|c|}
\hline BİLGI / INFO & ÖZ / ABSTRACT \\
\hline $\begin{array}{l}\text { Geliş/Received: } 25.05 .2021 \\
\text { Kabul/Accepted: } 20.06 .2021\end{array}$ & $\begin{array}{l}\text { Bu araştırma, Aşağı Garzan Havzası́nda yerleşim yerlerinin bulunduğu alanın arkeolojik anlamından } \\
\text { ziyade morfolojik özellikler, jeomorfolojik birimlerle ilişkiler ve arazi kullanım özellikleri bağlamında } \\
\text { ele alınmıştı. Fiziksel çevre faktörlerinin sosyal çevredeki yansımaları izlenerek farklı dönemlerdeki }\end{array}$ \\
\hline $\begin{array}{l}\text { Anahtar Kelimeler: } \\
\text { Yerleşim stratejisi } \\
\text { Jeomorfoloji } \\
\text { Arkeoloji } \\
\text { Aşağı Garzan Havzası } \\
\text { Keywords: } \\
\text { Settlement strategy }\end{array}$ & $\begin{array}{l}\text { yerleşim stratejileri ortaya çıkarılmaya çalısıılmışttr. Her bir yerleşim tek tek incelenmekle birlikte, } \\
\text { çağdaş yerleşimlerin ortak özellikleri ve farklılıkları CBS ortamında analiz edilerek yorumlanmıştı. } \\
\text { Ayrıca aynı dönemdeki yerleşim alanının morfometrik verileri belirlenerek Aşağı Garzan Havzası } \\
\text { dönemsel uygunluk analizleri de yapılmıştır. Analize göre iskân edilen alanların anlamı belirlenmiş } \\
\text { ve tartışımıştır. Sonuç olarak, Aşağı Garzan Havzası'ndaki farklı topluluklar, doğal ortamın uygun } \\
\text { olduğu alanları kullanmıs, doğal çevrenin özelliklerine göre farklı yerleşim stratejileri geliştirmiş, } \\
\text { kültürel çevre tercihlerine ve dönemsel kültürel dinamiklerine göre farklı fiziksel ortamı tercih et- } \\
\text { mişlerdir. }\end{array}$ \\
\hline
\end{tabular}

*Sorumlu yazar/Corresponding author: (S. Sarıaltun) savassarialtun@gmail.com

DOI: $10.17211 /$ tcd.942857

\section{Atf/Citation}

Sarıaltun, S. (2021). Arkeolojik yerleşim yerleri ile jeomorfoloji arasındaki etkileşim: Aşağı Garzan Havzası örneği. Türk Coğrafya Dergisi, (77), 195-210.

https://doi.org/10.17211/tcd.942857

\begin{abstract}
This research has been conducted in the context of morphological features, relations with geomorphological units and land use patterns rather than the archaeological meaning of the area where settlements are located in the Lower Garzan Basin. By following the reflections of physical geographic factors in the social environment, settlement strategies in different periods have been tied to be revealed. Although each settlement zone and its surrounding areas are examined separately, the common features and differences of the contemporary settlements have been analyzed and interpreted through Geographic Information System. Additionally, the morphometric common features of the settlement area during the same period were identified and periodic suitability analysis of the Lower Garzan Basin was examined as a result of the overlap analysis. Based on these analyzes, the meaning of the inhabited areas was both formulated and discussed. Thus, the paper argues that different communities in the Lower Garzan Basin established their settlement according to the environmental conditions which influenced their culture and periodic cultural dynamics.
\end{abstract}

\footnotetext{
1 Bu çalışmada Aşağı Garzan Havzası'nda jeomorfolojik özelliklerin arkeolojik yerleşmelere etkisi (Sarıaltun 2020) ile The Neolithic architectural structures and cultural landscape of Sumaki Höyük (Sarıaltun, 2019) başlıklı doktora tezlerinden faydalanılarak hazırlanmıştır.

2 In this study were prepared from the the doctoral theses titled Geomorphological Impact on Archaeological Settlements Pattern in the Lower Garzan Basin (Sarıaltun 2020) and The Neolithic architectural structures and cultural landscape of Sumaki Höyük (Sarıaltun, 2019).
} 


\section{Extended Abstract} Introduction

The settlement strategy is mainly related to its natural surroundings. The natural conditions of the existing outer space and the stability and variability of these conditions are the primary elements of choosing the settlement space. A secondary element is the culture of the community or communities that choose a certain area in this natural environment. Regarding this inextricable relationship between people and the environment, different cultural dynamics and social structures may form. Material cultural elements which express experiences and environmental conditions are generally judged in terms of time and space. Communities choose a place like their living space and where they live should not only be considered as a shelter but a habitation area as well. At the same time, space is a means of self-expression and evolves under the influence of social structure and the environment.

\section{Data and Method}

The Tigris River and its tributaries define the hydrography of our study area. The Upper Tigris Basin has three basins, namely, the Garzan, Bothan and Batman Stream basins. With a length of nearly $170 \mathrm{~km}$ in a north-south direction, the Garzan Stream watershed is divided into four sections due to differences in both the fluvial regime energy and the geomorphology. The geomorphological features of the Lower Garzan Basin were shaped primarily by the processes mentioned up to this stage and by local lithological and tectonic factors. The last terrestrial processes started in Upper Miocene and the subsequent interaction of internal and external forces is the main determinant of the geomorphological features. In addition to climatic changes in Quaternary, human influence from the beginning of the Holocene is also a determining factor in the current geomorphological features.

The Lower Garzan Basin located which is surrounded by Kıradağ and Mount Raman to the west and the Garzan and Kentalan anticlines to the east, in the Upper Tigris Basin. The lowest point of the Lower Garzan Basin is $446 \mathrm{~m}$ at its junction with the Tigris River while the highest point of the Garzan Anticline is Maharakeri Tepe $(1067 \mathrm{~m})$ and the highest point of the Kentalan Anticline is Güneydilek Tepe (1531 m). On the southwest slopes of the Garzan and Kentalan anticlines, landforms unique to fault topography have developed such as fault scarps, offset ridges and valleys, fault steps, alluvial fans and piedmont plains. The formation of the current landforms in the Lower Garzan Basin occurred as a result of polycyclic and polygenic processes. This is due to continental processes experienced from Upper Miocene to the present day. While the general orientation of Mount Raman and the Mardin Threshold to the south is E-W, the Lower Garzan Basin extends NW-SE. The projection of the Lower Garzan Basin is 426.8 $\mathrm{km}^{2}$, which reaches a total area of nearly $433 \mathrm{~km}^{2}$ when the topographic characteristics are noted. With a mean elevation of $697 \mathrm{~m}$, the most extensive area of the Lower Garzan Basin forms an elevation step of 446-646 m (21.8\%).

\section{Discussion}

A total of twenty-two archaeological settlements of different qualities were identified during the surveys carried out on different dates in the Lower Garzan Basin. Only one settlement was identified in the study area during the Neolithic Period, which is one of the cultural phases of the Early Holocene period. A total of 21 settlements were identified between the EBA-IA periods. Even this data shows that the Lower Garzan Basin was not very suitable for settlement or was not preferred by ancient communities, at least until 5000 years ago. Widespread landslide traces and remains in the study area and external physical factors such as landslides and/ or floods were determined in detail in the archaeological excavations of both Sumaki and Çemialo Ridge and Gre Amer. The only Neolithic settlement found was found above the plio-quaternary erosional surface at an altitude of 700-710 m. No settlements representing this period were found or could not be found near the Garzan Stream or in the lower reaches of the basin. One of the reasons for the abandonment of the Neolithic period settlement is thought to be the increased floods or overflows in the last phases. However, it seems that the Lower Garzan Basin was not used or preferred between about 8000 years before the Sumaki Höyük settlement was abandoned and 5000 years before today. There is resettlement in the basin with 5000 years before today. In this period, which coincides with the EBA in archaeological terms, settlements were generally established on the banks of the river and in relatively fertile areas. In 4000 years before today, the settlement of the basin has become more intense. In this cultural phase defined as the Middle Bronze period, communities preferred not only the river banks but also the farther and higher parts of the Garzan Stream as settlements. Before today, by 3200 , the settlements spread to almost the entire basin and especially the southern parts, which were not used before, are now used by the communities.

\section{Results}

The communities and/or groups that used the Lower Garzan Basin during the Neolithic and later period determined their settlement strategies according to the characteristics of the physical environment, socio-economic preferences and periodically cultural dynamics or due to political factors, or did not prefer the Lower Garzan Basin.

\section{Giriş}

Bu çalışma, Dicle Nehri'nin önemli kollarından biri olan Garzan (Yanarsu) Çayı ve Havzası'nın aşağı kesimini tanımlayan bir alt havza olan Aşağı Garzan Havzası'nın (Şekil 1) jeomorfolojik ve arkeolojik boyutunu ele almaktadır. Bu alt havzanın sınırlarını kuzeyde İkiköprü Boğazı, güneyde Ulular Boğazı ile Dicle Nehri, doğuda Garzan ile Kentalan antiklinalleri ve batıa Kıradağı ile Raman Dağı oluşturmaktadır. Bu çalışmanın ilk amacı ve ana hedefi; bu çalışmada sınırları detaylarıyla belirtilen Aşağı Garzan Havzası'nın jeomorfolojik özelliklerini ve gelişim seyrini belirleyerek farklı dönemlere tarihlenen arkeolojik yerleşim yerlerinin bulunduğu alandaki fiziki ortam özelliklerini ortaya koymak ve yerleşim stratejisinde nasıl bir etkisi olduğunu tartışmaktır. 
Garzan Havzası, Diyarbakır Havzası içinde 2838 km²'lik yüzölçümüyle oldukça büyük bir alan kaplar. Garzan Havzası'nın ana kaynak alanı kuzeyde Mutki Vadisi'nde başlar ve güneyde gömük menderesli vadi özelliğindeki íkiköprü ve Ulular boğazlarından geçerek Dicle Nehri'yle birleşir. Aşağı Garzan Havzası, Dünya Jeodezi Sistemi (WGS84) koordinatna göre: $37^{\circ} 56^{\prime} 15.22^{\prime \prime} \mathrm{K}-41^{\circ} 20^{\prime} 08.05^{\prime \prime} \mathrm{D}$ ile $37^{\circ} 43^{\prime} 54.75^{\prime \prime} \mathrm{K}$

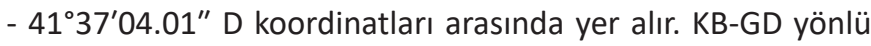
kuş uçumu, yaklaşık 35 km uzunluğundaki havza 426,8 km²lik bir alan kaplar.

Yukarı Dicle Havzası'nda yerleşim yeri seçimi ve nedensellikleri ile coğrafik ilişkisinin ortaya konduğu çalışma hemen hemen yok gibidir. Bununla birlikte söz konusu alanda birçok yerleşim yeri arkeolojik yöntemlerle kazılmış, çeşitli amaçlarla onlarca yüzey araştırması yapılmıştır. Ancak tespit edilen ve/ veya kazılan yerleşmeler tekil anlamda yerleşim stratejisi ve jeoarkeolojik yorumları yapılmış olmasına karşın; yer seçimi bağlamında tümel incelemeler maalesef yaygınlık kazanmamıştır. Doğan'ın (2005) çalışması dışındakilerin hemen hemen tümü ya yerleşim yeri özelinde tikel bir çalışma ya da belirli bir dönemi kapsayan (Parker, 2001) tümel çalışmalardan ibarettir. Elinizdeki bu çalışmada Aşağı Garzan Havzası'nın Neolitik Dönem'den Demir Çağ'ı sonuna kadar geçen yaklaşık 9000 yılda sürede, farklı niteliklerdeki yerleşim stratejilerinin özellikleri ve nedensellikleri hem jeomorfolojik hem de arkeolojik veriler kullanılarak tartışılmıştır.

\section{Yöntem}

Aşağı Garzan Havzası'nda 2008-2015 yıllarında yaklaşık 100 gün ayrıntılı jeomorfolojik arazi tarama çalışmaları gerçekleştirilmiştir. Bu çalışma kapsamında incelenen sahaya ait oluşturulan haritalarda, Harita Genel Müdürlüğü tarafindan hazırlanmış 1/25.000 ölçekli topografya haritaları ve sayısal yükselti verilerinden yararlanılmıştır. Söz konusu sahaya ait Maden Teknik ve
Arama Genel Müdürlüğü tarafindan hazırlanan $1 / 100.000$ ve $1 / 25.000$ ölçekli jeoloji paftaları (Şenel, 2007; 2008) ile 1/25.000 ölçekli heyelan paftalarından da (Duman vd., 2009) faydalanılmıştrr. Elde edilen veriler MapInfo 17.0 ile Datamine Discover \& 3D Bundle 2017 programları kullanılarak haritalara işlenerek farklı niteliklerde modeller oluşturulmuştur.

CBS teknolojisi kullanılarak sayısal modellerin yanı sıra saha çalışmasından elde edilen veriler ile yerleşmelerin morfometrik özellikleri Analitik Hiyerarşi Proses (AHP) yöntemiyle de değerlendirilmiştir. Derecelendirme de yerleşim yerlerinin sayısallaştırılmış özellikleri dikkate alınmıştır. Birinci aşamada elde dilen verilerin bu çalışmaya katacağı etkileri belirlenmiş ve rasyonel karar vermede kullanılacak değerlerden hiyerarşik bir yapı oluşturulmuştur. Bu hiyerarşik yapının oluşturulmasının en önemli nedeni, elde dilen saha verilerinin ortaya çıkarabileceği en iyi alternatifleri seçmek ve modellerin sınanabilir olmasıdır. Özellikler yerleşim yeri seçiminde geçmiş toplumların iskan alanı seçim kriterlerini yorumlamak için AHP ihtiyaç duyulmuştur. Bu bağlamda bir yerleşim yeri seçiminde Gazran Çayına uzaklık, yükselti kriterleri ile yerleşim alanı ve yakın çevresinin eğim özellikleri etkenleri incelenmiştir. Bu inceleme ve hiyerarşik yapının oluşturulmasında iki yöntem kullanılmıştır. Birinci yöntem Aşağı Garzan Havzası'nı iskân eden toplulukların seçtiği yerleşim yerleri, her dönem için ayrı ayrı, incelenmiş ve ortak noktalar belirlenmiştir. İkinci yöntem ise arkeolojik yerleşim yerlerinden bağımsız olarak Garzan (Yanarsu) Çayı'na en yakın alanlar (suya yakınlık), heyelan vb. etkenlerin en az tespit edildiği 446-600 rakımlı alanlar (en elverişli yükseklikler), eğimin en az olduğu düz veya dalgalı düzlük alanlar (elverişli yüzey kullanım alanı) belirlenmiştir.

Yerleşim yeri morfometrik özellikleri dikkate alınarak oluşturulan formül her dönem için ayrı ayrı değer aralıkları tanımlanmıştır. CBS tabanlı yerleşim yeri değer analizlerinde kullanılan formüller aşağıda sunulmuştur.

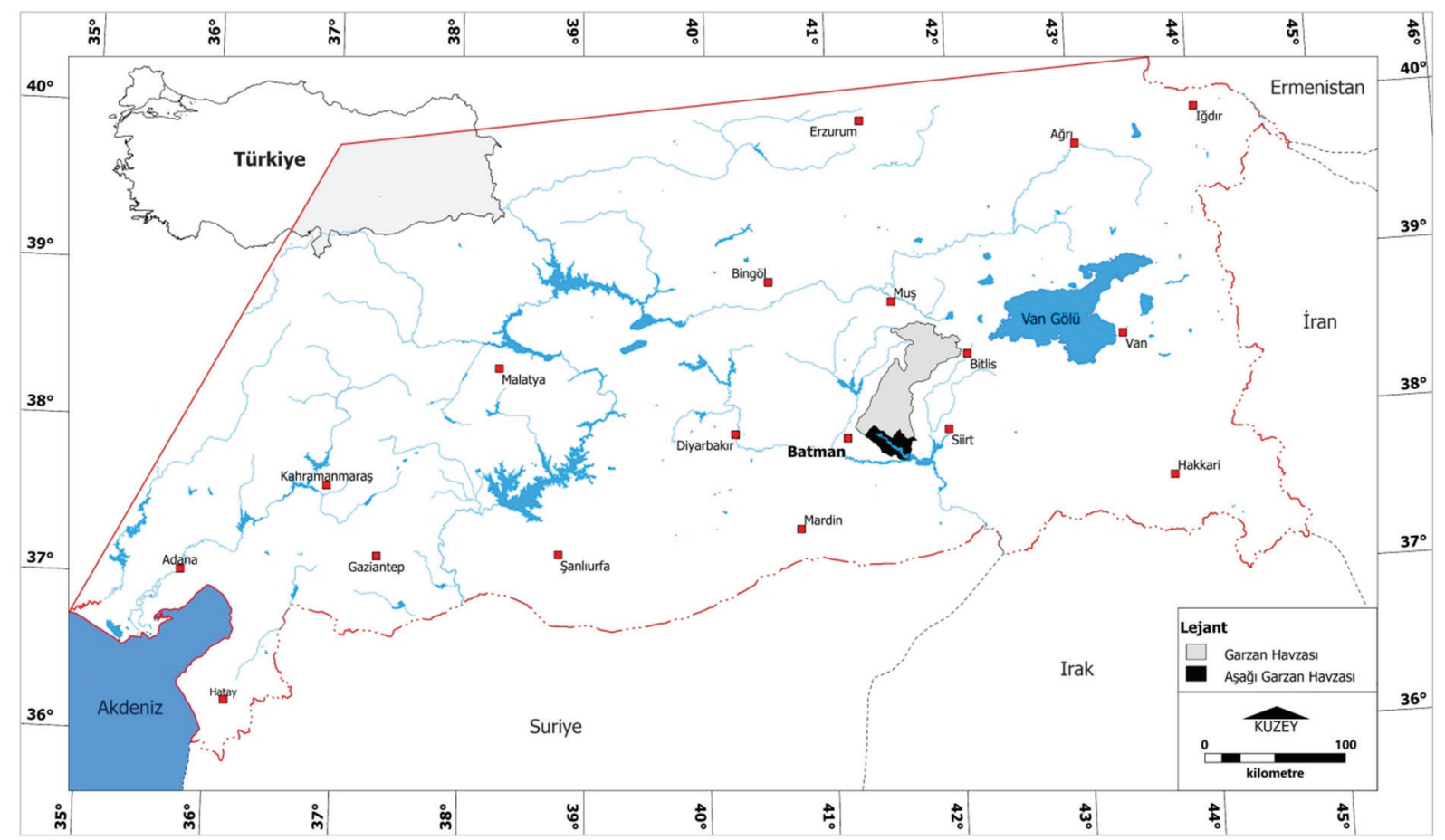

Şekil 1. Çalışma sahasının konumu ve sınırlarını gösteren harita.

Figure 1. Map showing the location and boundaries of the study area. 
a. Neolitik Dönem için: (Input_1="600-800") \& (Input_2="Az Eğimli yamaçlar") \& (Input_3="Orta mesafe ") \& (Input_4="2") \& (Input_5="III")

b. Ilk Tunç Çağ İçin: (Input_1="446-600") \& (Input_2="Dip Slope") \& ((Input_3="Çok yakın mesafe") | (Input_3="Yakın mesafe")) \& ((Input_4="1") | (Input_4="2")) \& ((Input_5="III") / (Input_5="IV") / (Input_5="VII"))

c. Orta Tunç Çağ İçin: (Input_1="446-600") \& ((Input_2="Sloping Slope") / (Input_2="Dip Slope")) \& ((Input_3="Çok yakın mesafe") / (Input_3="Yakın mesafe")) \& ((Input_4="1") I (Input_4="2")) \& ((Input_5="III") / (Input_5="VII"))

d. Demir Çağ için: (Input_1="446-600") \& ((Input_2="Sloping Slope") / (Input_2="Dip Slope")) \& ((Input_3="Yakın mesafe ") / (Input_3="Orta mesafe ")) \& ((Input_4="2") | (Input_4="3")) \& ((Input_5="III") | (Input_5="VI") | (Input_5="VII"))

İkinci aşamada ise arkeolojik yaklaşım ön plana çıkartılmış ve kültürel etmenler bağlamında değerlendirmeler yapılmıştır. Aşağı Garzan Havzası'nda farklı amaçlarla yapılmış saha çaIışmalarında (Algaze vd., 1991; Benedict, 1980; Erim-Özdoğan \& Sarıaltun, 2011) saptanmış arkeolojik yerleşim yerleri CBS ortamına aktarılarak farklı nitelikte arkeolojik modeller de oluşturulmuştur. Bu çalışmada; özellikle 2002 yılında gerçekleştirilen "Ilısu Baraj Alanı Garzan Vadisi ve Batman Çayı Çevresi Kültür Envanteri" çalışmasında elde edilen yerleşim lokasyonları dikkate alınmıştır. Bununla birlikte Sumaki Höyük ve Çemialo Sırt yerleşim yerlerinde yürütülen arkeolojik kazı çalışmalarıyla eşgüdümlü gerçekleştirilen jeomorfolojik - jeoarkeolojik saha çalışmaları verilerinden de yararlanılmıştır.

\section{Bulgular}

\subsection{Garzan Havzası Bölümleri ve Genel Özellikleri}

Yukarı Dicle Havzası'nda yer alan ve K-G yönlü, yaklaşık 170 km uzunluğundaki Garzan (Yanarsu) Çayı drenaj alanı gerek nehir sistemi gerekse morfometrik farklılıklar göz önüne alınarak dört bölüme ayrılmıştır (Şekil 2). Mutki ilçesi sınırları içinde kalan Boğazönü Köyü'nün güneydoğusunda yer alan gömük menderes karakterli Keyburan Boğazı'nın kuzeyinde yer alan D-B yönlü Karasu Deresi ve tali kollarının oluşturduğu drenaj alanı 1. Bölüm olarak tanımlanmaktadır. Bu bölüm aynı zamanda Mutki-Hoyt Platosu olarak da adlandırıır (Tolun, 1962). Garzan (Yanarsu) Çayı'nın ilk kaynak alanı olan bu bölümde vadi yapısının D-B yönlü uzanmasındaki en belirleyici etken Kavakbaşı Fayı'dır.

Keyburan Boğazı'yla başlayan ve Kozluk ilçesinin doğusuna kadar devam eden, engebeli dağlık alan ise 2. Bölüm olarak tanımlanmaktadır. Bu bölümde Garzan (Yanarsu) Çayı oldukça derin bir vadide akar ve az da olsa küçük parçalar şeklinde aşınım yüzeyleri görülür. "V" şeklinde bir vadide akan Garzan (Yanarsu) Çayı'na, bu alanda bir kısmı mevsimlik dere olan çok sayıda tali yan kol bağlanmakta olup; Garzan (Yanarsu) Çayı ismini de buradan alır.

Kozluk ilçesi ile İkiköprü Boğazı arasındaki alan 3. Bölüm olarak tanımlanmaktadır. Bu bölüm aynı zamanda Garzan (Yanarsu) Çayı su debisinin en düşük seviyelere indiği, eğimin oldukça azaldığı bir topografyadır. Bu durumun en önemli jeomorfolojik göstergesi Garzan (Yanarsu) Çayı́nın belirgin olarak örgülü bir yatak içinde akması ve çayın her iki yamacında eski ve yeni alüvyon birikimlerin rahatlıkla gözlemlenmesidir. Holosen Dö-

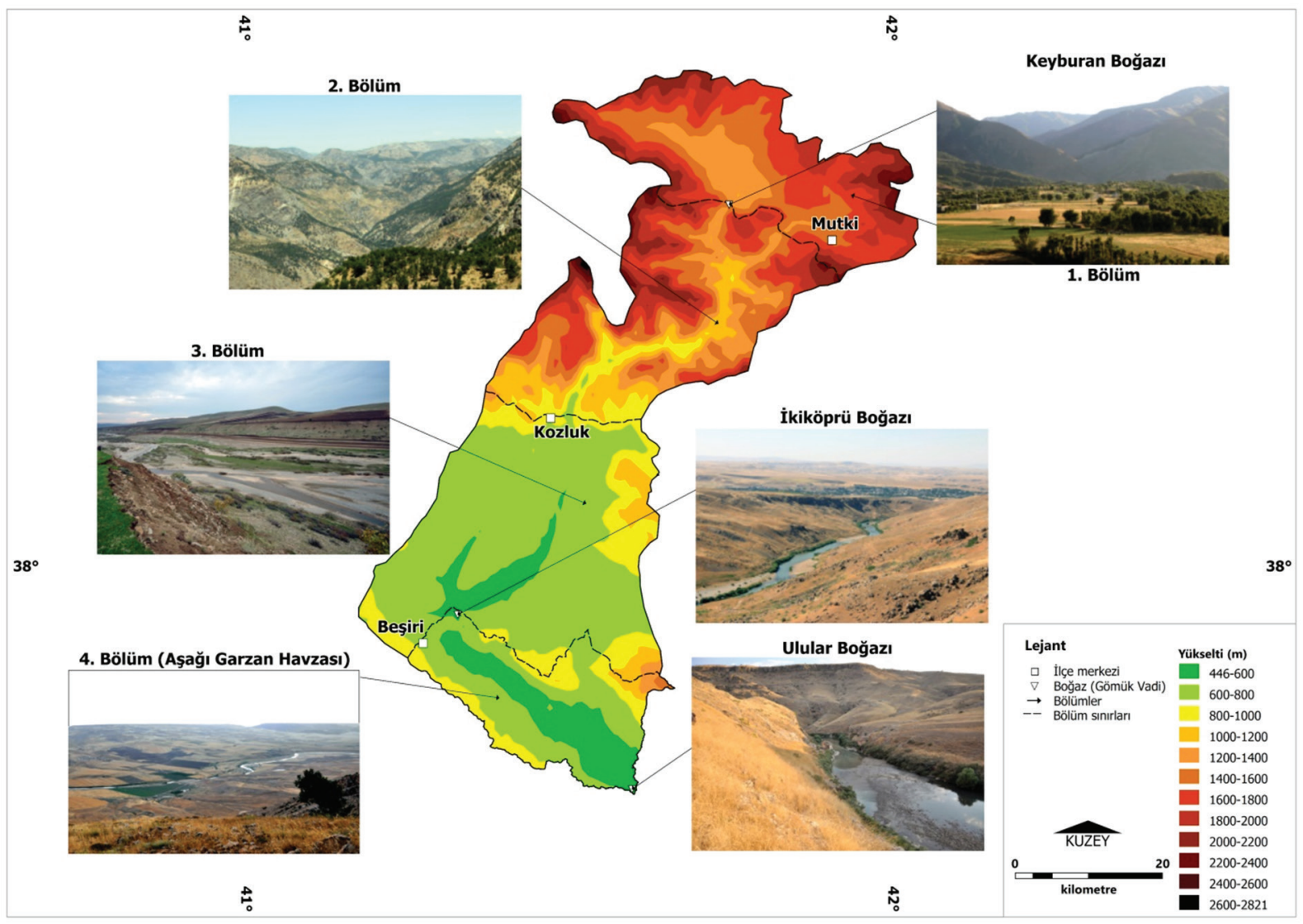

Şekil 2. Garzan Havzası sayısal yükselti modeli ve alt bölümlerinin sınırları, görsel malzeme desteğiyle.

Figure 2. Garzan Basin digital elevation model and the boundaries of its subsections, with the support of visual materials. 
nem killi depoları ile ince taneli kum birikim alanlarının varlığı bu bölümde nehir akış hızının düştüğünü ve biriktirmenin arttığını gösteren bir diğer kanıttır.

İkiköprü Boğazı ile güneyde Garzan (Yanarsu) Çayı'nın Dicle Nehri'ne kavuştuğu dirseğe kadarki alan bu çalışmada 4. Bölüm olarak adlandırılmıştır. Bu alanın başlangıcında Garzan (Yanarsu) Çayı yaklaşık 90\%lik bir açıyla güneye yönelir. AltınIı'ya (1966) göre: “...dağ sıralarını takibeden akarsuların kapmalarla 90"lik bir açıda yön değiştirmesi olağandır”. Ancak bu alanda göz önüne alınması gereken bir diğer neden, bu keskin dönüşün bulunduğu alanın Garzan Antiklinali batı yamacındaki fay hattıla da ilişkisidir. Hem kapma hem de ötelenme nedeniyle Garzan (Yanarsu) Çayı yatağı güneye yönelmiştir. 4. Bölüm bu çalışmada üzerinde durulan ve ayrıntılarıyla tartışılan alt havza olup; bundan sonra adlandırması Aşağı Garzan Havzası olarak geçecektir (Şekil 3).

\subsection{Litolojisi ve Tektonik Yapısı}

Araştırma sahasının güneyinde Arap Platformu'nun kuzey kısmı ve kuzeyinde Anadolu platosu yer alır. Bu iki ana kara arasında Toros orojenik kuşağının çok farklı jeolojik yapı ve birimlere sahip sütur zonu uzanmaktadır (Yeşilova \& Helvacı, 2011). Mardin Bloğu'nun kuzeyindeki sübsidans niteliğindeki Diyarbakır Havzası'nda birbirini takip eden antiklinal ve senklinaller görülmekte olup; Neojen birimlerin üst üste birikmesiyle oluşmuştur (Ardel, 1961). Havzanın kenar kısımlardaki kıvrılma ve bükülmenin yön değiştirmesinin ana nedeni, alanın kuzeyindeki Bitlis Masifi'dir (Tolun, 1962).

Çalışma sahasının en erken jeolojik birimini Geç Kratese - Paleosen yaşlı Germav Formasyonu temsil eder (Yılmaz \& Du- ran, 1997). Şırnak Grubu birimlerinden biri olan bu formasyon derin denizel ortamda çökelmiş ve genellikle killi-siltli ve marnlı dolgularla tanımlanmaktadır. (Yeşilova, 2012). Paleosen Dönem'in ikinci aşamasını temsil eden Eosen Dönemin'den itibaren Aşağı Garzan Havzası'nda, deniz ilerlemesine bağlı olarak, sakinleşen denizel ortamda oldukça kalın ve sık dokulu Midyat Grubu'na ait kireçtaşları istiflenmiştir. Bununla birlikte Eosen başlarında tektonik etkenler nedeniyle çalışma sahası genelinde birikme kısmen kesintiye de uğramıştır. Bu dönemde tektonik aktivite nedeniyle yükselen alanlarda aşınma oluşurken, şaryaj alanında genellikle kırmızı renkli karasal Gercüş Formasyonu çökelmiştir (Karadoğan, 2018). Çalışma sahasında Gerçüş Formasyonu'nun üzerinde genellikle Hoya Formasyonu uzanır. Garzan Antiklinali'nin dış kanatlarında ve vadinin en güney kesimlerinde Orta-Üst Eosen yaşlı Hoya Formasyonu yüzeylenir (Şekil 4) Hoya Formasyonu'nun litolojisi ağırlıklı olarak kireçtaşı ve dolomittir.

Üst Eosen-Oligosen yaşlı Germik Formasyonu (Tolun, 1962) sınırlı ve evaporitik koşullu regresif deniz ortamında (Karadoğan, 2018; Yeşilova \& Helvacı, 2011) oluşmuştur. Garzan Antiklinali'nin kuzey kısmındaki jips fasiyesi de bu formasyona aittir. Ancak bu jips seviyeleriyle karışık dolomit ve kireçtaşının tabakasal birlikteliği, çökelmenin eş zamanlılığına işaret eder.

Oligosen'in başında deniz çekilmesine bağlı olarak karasal ortama geçilmesi nedeniyle biriktirme aynı oranda devam etmemektedir. Dolayısıyla Alt Miyosen Dönemi'nde Aşağı Garzan Havzası'nda stratigrafik bir boşluk oluşturmuştur. Üst Miyosen Dönem'de denizel ortam iyice sığlaşmıştır. Böylece, karasal ortamda gelişen flüvyal biriktirmeyle birlikte Şelmo Formasyonu'na ait killi-çakıllı dolgular çalışma sahası ve çevresinde

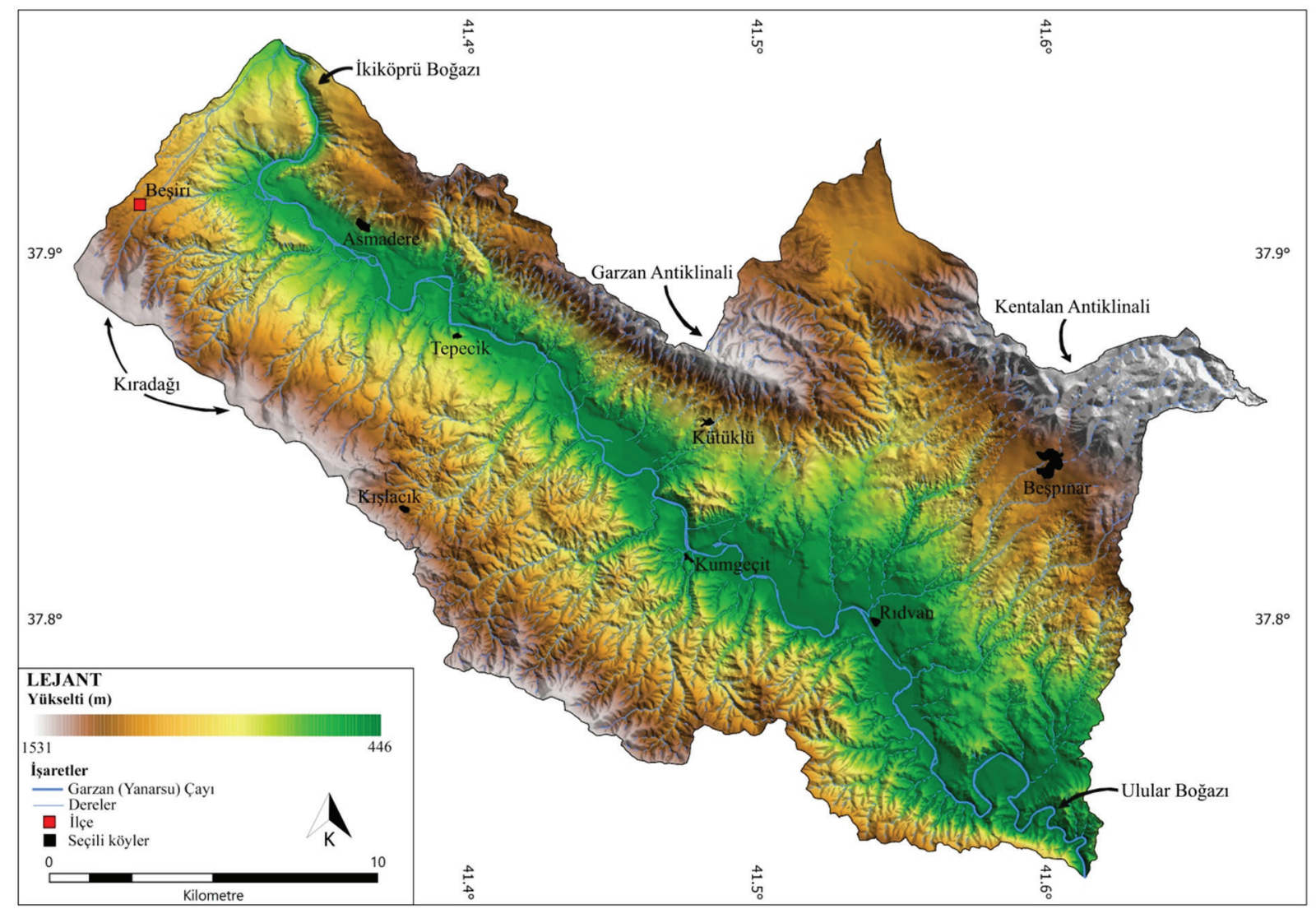

Şekil 3. Aşağı Garzan Havzası sayısal yükselti modeli.

Figure 3. Digital elevation model of the Lower Garzan Basin. 


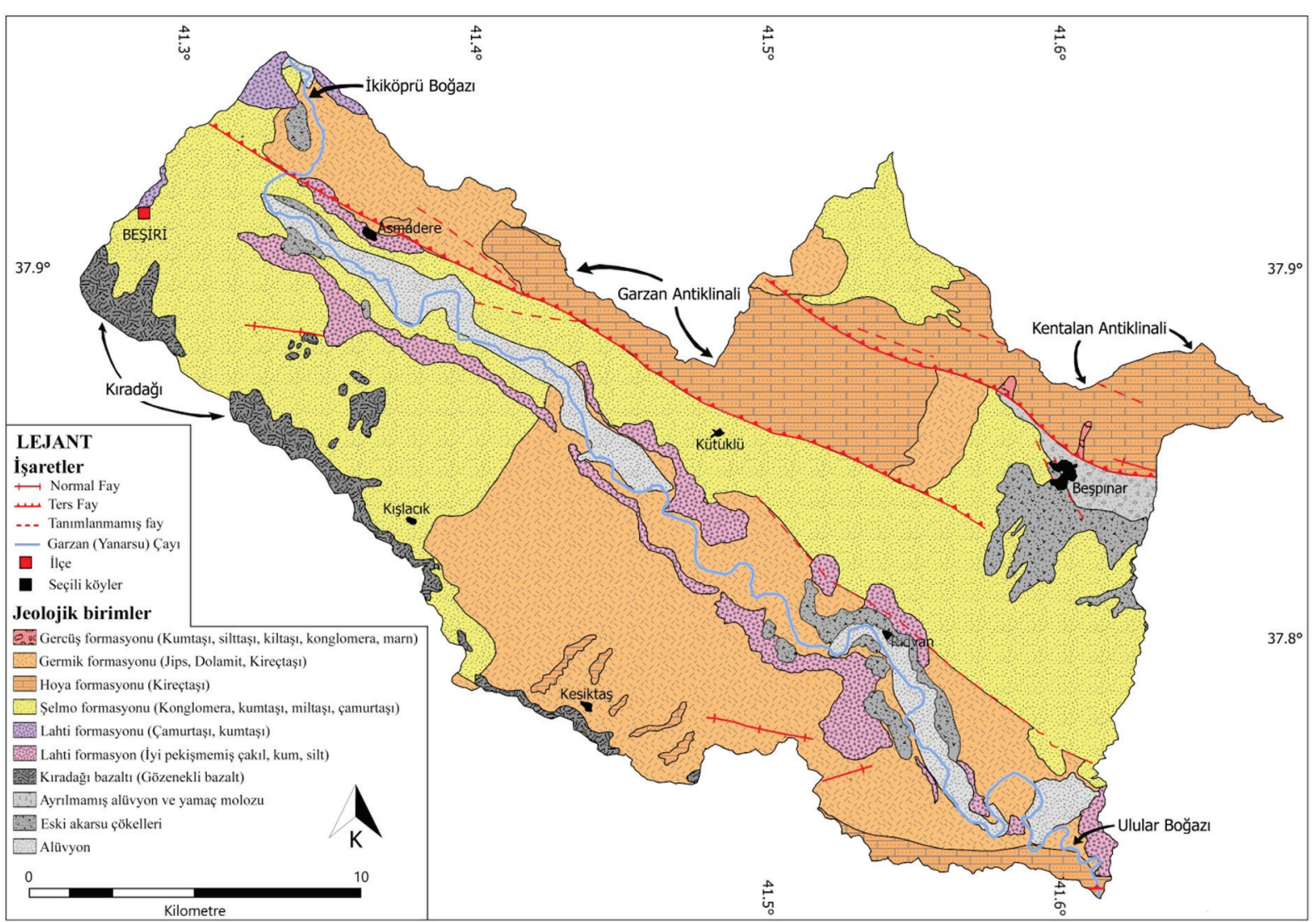

Şekil 4. Aşağı Garzan Havzası jeoloji haritası (Şenel, 2007; 2008; Yeşilova, 2012 yararlanılarak oluşturulmuştur).

Figure 4. Geological map of the Lower Garzan Basin (Created using from Şenel, 2007; 2008; Yeşilova, 2012).

birikme ortamına kavuşmuştur. (Şimşek, 1979). Orta-Üst Miyosen yaşlı Şelmo Formasyonu (Sunkar \&Tonbul, 2012), çalışma sahasında en geniş alanda yüzeylenen jeolojik birimdir. Bu formasyonun üzerinde de yer yer yerel Kuvaterner Dönem bazalt akıntıları ile Lahti Formasyonu'nun çakıllı birimleri uzanır. Lahti Formasyonu zayıf boylanmalı kalın tabakalı, killi ve kalkerli, grimsi renkli konglomera ve kumtaşlarından oluşan tabakalarıyla tanımlanır. Formasyonun tabakalarının yatay yönlü olması bu jeolojik birimin tektonizma sonrası çökeldiğini gösterir (Yeşilova, 2012).

K-G yönlü sıkışmanın ürünü olan Karacadağ volkanizması temelinde şekillenen Güneydoğu Anadolu volkanizması Üst Miyosen'den başlamış ve tarihsel devirlere kadar süregelmiştir. Plato bazaltları şeklinde gelişen Karacadağ volkanizması genel olarak kuzeybatıdan güneydoğuya doğru gençleşme gösterir ve bazalt akıntılarla çevreye yayılır (Tolun, 1962). Kıradağ Bazalt, Üst Miyosen yaşı Şelmo Formasyonu ile Pliyosen yaşlı Lahti Formasyonu'nun üzerindedir (Yılmaz \& Duran, 1997). Bundan dolayı söz konusu bazalt akınt Üst-Pliyosen-Pleistosen Dönem'e tarihlendirilmektedir (Yeşilova \& Helvacı, 2011). Bu birim işlenebilir taş malzeme açısından, arkeolojik yerleşmeler için gerek alet yapımında gerekse mimari eleman olarak önemli bir kaynaktır. Neolitik Dönem'e tarihlenen Sumaki Höyük'te Kıradağı Bazalt'na petrografik yapısıyla benzer çok sayıda bazalt öğütücü alet bulunmuştur. XRF analizlerine göre Kıradağı bazaltı ile Sumaki Höyük öğütücü aletleri ve çanak çömlek yapımında kullanılan kilin içine katkı malzemesi olarak eklenen bazalt kırıntılar birbiriyle çok uyumludur (Sarıaltun, 2019).

Çalışma sahası ve çevresinin şekillenmesinde Orta Eosen sonu ve Alt Miyosen tektonizmaları etkilidir. Oluşum yaşı bölgenin ana tektonizmasının gerçekleştiği dönemden daha genç olan Hoya Formasyonu'nda tektonik etkiler birçok çalışmada saptanmamıştır (Yeşilova, 2012). Ancak bu çalışmada Şelmo ile Lahti formasyonlarında tektonik etkinin devamlılığını gösteren delillere de ulaşılmıştır. Saha çalışmasında karşılaşılan bir yol kesitinde Hoya formasyonu üzerindeki Şelmo ve Lahti formasyonlarında da fay izleri çok dar alanlarda da olsa belirlenmiştir. Keza Yukarı Dicle Havzası'nda yürütülen arkeolojik kazı çalışmalarında farklı dönemlerde deprem izleri tespit edilmiştir. Bunlar arasında en belirgin deprem izleri Salat Tepe yerleşmesinde saptanmıştir. Salat Tepe arkeolojik yerleşmesinde günümüzden yaklaşık 4000 yıl öncesini temsil eden Orta Tunç Çağı kültür dolgusu içinde tespit edilen kerpiç duvarların depremle yıkıldığı ileri sürülmektedir (Esentürk vd., 2007; Ökse vd., 2009). Yine; Yukarı Dicle Havzası'nda yer alan Hırbemerdon yerleşmesi Alt-Evre A'da (Laneri vd., 2006), Kenan Tepe C1 açmasında açığa çıkarılan Orta Tunç Çağı'na tarihlendirilen bir bina (Parker \& Swartz-Dodd 2005), Ziyarettepe yerleşmesindeki yanık bina içinde ve Orta Tunç Çağı'na tarihlendirilen ezilmiş çanak çömlek parçaları (Matney vd., 2002) Orta Tunç Çağı kültür dolgusundaki çeşitli yıkıntılar Salat Tepe yerleşmesi deprem yorumunu destekler niteliktedir. Aşağı Garzan Havzası'nda özellikle Çemialo Sırt kazılarında deprem nedeniyle dağılmış çanak çömlek kalıntıları ile devrilmiş taş duvarlar tespit edilmiştir (Erim-Özdoğan \& Gündüzalp, 2018). Tüm bunlar birlikte değerlendirildiğinde çalışma sahasında deprem etkisinin Hoya Formasyonu sonrasında da devam ettiği dolayısıyla genç fayların en azından günümüzden 4000 yıl önce aktif olduğu arkeolojik kazı kayıtlarından da teyit edilmektedir. Ayrıca çaış̧ma sahası yakın çevresinde tarihi dönemlerde de birden çok şiddetli depremlerin gerçekleştiği kayıt altına alınmıştır (İmamoğlu \& Çetin, 2007). 


\subsection{Drenaj Özellikleri ve Nehir Sistemi}

Çalışma sahamızın hidrografyası Dicle Nehri ve kollarıyla tanımlanmaktadır (Tolun, 1962). Aşağı Garzan Havzası'nın kuzey sınırı olan ve İkiköprü beldesinin hemen güneyinde yer alan İkiköprü Boğazı'na giren Garzan (Yanarsu) Çayı, bu gömük vadinin bitişiyle birlikte Ulular Boğazı'na kadar tabanlı vadi özelliği kazanır. İkiköprü Boğazı'nın uzanışı KD-GB iken boğaz çıkışından itibaren keskin bir menderi hareketle havzanın genel doğrultusu olan KB-GD doğrultusunda akar (Şekil 5).

Garzan (Yanarsu) Çayı, araştırma sahamıza girdikten sonra, 55,87 km uzunluğunda, hafif örgülü nehir yatağında akışı sonrasında, Ulular Boğazı'nı aşarak Dicle Nehri ile birleşir. Garzan (Yanarsu) Çayı'nın Aşağı Garzan Havzası'na girdiği alan ile çıkthğı alan arasında $100 \mathrm{~m}^{\prime}$ lik yükselti farkına bağlı olarak akarsu boyunca yatak eğimi \% 0,18, kıvrımlanma oranı ise 1.27 'dir. Aşağı Garzan Havzası drenaj yapısı litoloji ve tektonizma kontrolünde genelde asimetrik bir yapı, yerelde kısa mesafelerde farklılaşan bir drenaj yapısı sergiler.

Kaynağını Kıradağı'ndan alan ve kuzeydoğu istikametinde akan Haraba Dere, Beşiri ilçesi içinde doğuya doğru dönerek Çamaşır Dere ismiyle Garzan (Yanarsu) Çayı'na dökülür. Topografik değerlendirme ve arazi gözlemleri Haraba Dere'nin daha önce akışına Yolkonak Köyü'nden devam eden Değirmen Dere ile birleşerek devam ettiği yönündedir (Şekil 5). Haraba Dere'nin, kapılarak yön değiştirmesinde Yolkonak Köyü yakınındaki bindirme hattı ile buna bağlı olarak havzanın doğu kısmında gerçekleşen yükselmenin belirleyici olduğu düşünülmektedir. Fay kontrollü yön değiştiren bir diğer dere ise Çaşorki Deresi'dir. K-G yönünde bir yatağa sahip bu dere Silaven ve Çupçura mevsimlik dereleriyle birleştikten sonra hemen hemen 90 derece- lik bir dönüşle akış yönünü doğuya çevirir. Bu aşamadan sonra Domuz Dere adıyla D-B yönünde akar. Deril Dere aynı zamanda Şelmo ile Germik formasyonlarının birbirine sınır oluşturduğu hattan ilerler. Germik Formasyonu'na göre daha gevşek dokulu Şelmo Formasyonu'na yatağını açan bu dere hemen güney tarafindaki Germik Formasyonu'na yönelmemiştir.

Aşağı Garzan Havzası, Gedikler Köyü çevresine kadar KB-GD uzanışlı, yaklaşık $11 \mathrm{~km}$ genişlikte dikdörtgen bir alan olarak devam eder. Bu kesimde Garzan (Yanarsu) Çayı, tektonik aktivitenin etkisine bağlı olarak havzanın doğusuna doğru kaymakta ve asimetrik bir vadi karakteri göstermektedir. Bu kesimde doğudaki dik ve çok dik yamaçlardan kaynağını alan akarsular daha çok mevsimlik akarsu niteliğindedir. Aşağı Garzan Havzası'nın KB-GD uzanışlı dikdörtgen yapısı Gedikler Köyü'nün güneyinde de devam etmekle birlikte, bu kesimde havza asimetrisi kuzey kesimin aksi yönündedir. Bu kesimde hem vadi genişliği $20 \mathrm{~km}$ 'ye ulaşmakta hem de akış yeri değişmekte ve Garzan (Yanarsu) Çayı artık havzanın batı tarafina yakın akmaktadır. Bu kesimde havzanın asimetrisinin değişmesinin nedeninin Garzan Antiklinali'nin son bulmasıla Kentalan Antiklinali'nin çevresine doğru genişlemesi ve yükselmesi olduğu öngörülmektedir. Ortaalan Köyü’nün kuzeyindeki sahada faylanma etkisi, dantritik ve kancalı drenaj ağının oluşmasına yol açan nedenlerden biridir. Aynı bölgede Ortaalan Köyü ile Yeşiloba köyü arasındaki kesimde (Garzan Antiklinali bat etekleri) paralel drenaj ağı hakimdir. Bu bağlamda drenaj ağının salt faylanma ile oluştuğu ileri sürülemez. Yukarıda anlatilan alanda faylanma ile birlikte aktif heyelan alanları da kaydedilmiştir. Dolayısıyla dantritik ve kancalı drenaj ağının bu bölgede gelişmesinin faylanma ile birlikte oluşan heyelanların derelerin parçalanması ve/veya yatak farkılışmasını da sağlamış gibidir.

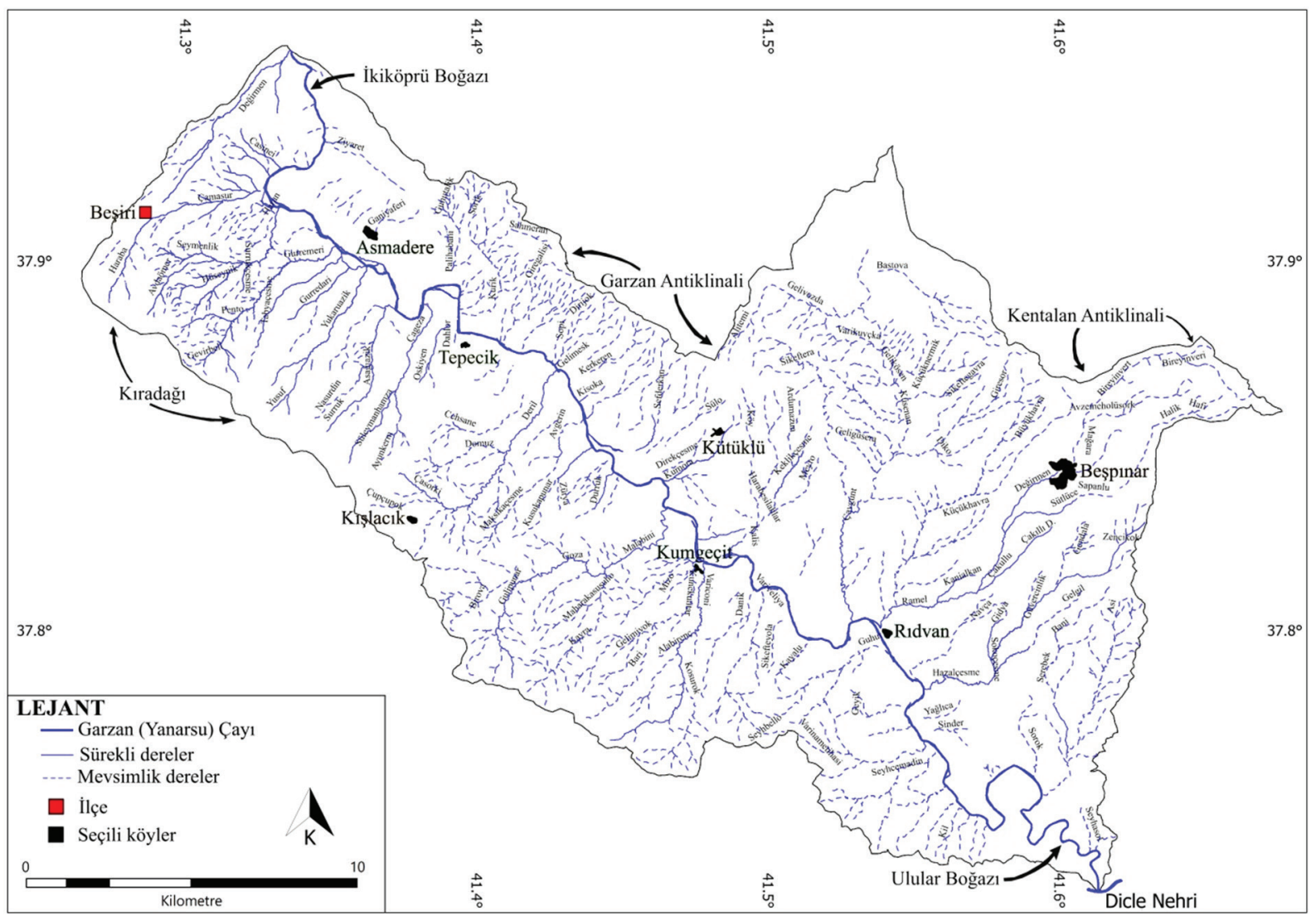

Şekil 5. Aşağı Garzan Havzası'nın drenaj ağı haritası (Harita Genel Müdürlüğü’nde temin edilen sayısallaştırılmış veriler kullanılarak oluşturuldu). Figure 5. Drainage network map of the Lower Garzan Basin (created using the digitized data obtained from the General Directorate of mapping). 
Benzer jeomorfolojik özellikler Yontukyazı Köyü ile Beşiri ilçesi arasındaki bölge ve Kışlacık - Alacak-Kumgeçit köyleri arasında kalan alan için de geçerlidir. Söz konusu bu alanlarda paleo ve aktif heyelan izleri, şekilleri ve oluşumları yaygındır.

\subsection{Kütle hareketleri ve Heyelanlar}

Aşağı Garzan Havzası kütle hareketleri ana hatlarıyla üç mekanizmayla oluşmuştur: göçme ya da kayma, akma ve düşme şeklindedir. Göçmeler, genellikle büyük ölçekli heyelan alanlarına karşılık gelirken; kayma görece daha küçük alanları etkiler. Göçme hareketi, özellikle Kıradağı eteklerinde heyelan topuklarıyla birlikte birden fazla basamak oluşturmuştur. Kayma yüzeyi genellikle yayvan ve kavislidir. Akma şeklindeki kütle hareketleri daha çok killi, kumlu ve kırıntılı yapıya sahip arazilerde görülmektedir. Özellikle Şelmo Formasyonu'nun baskın jeolojik birim olarak yayıldığı Aşağı Garzan Havzası'nın batı yakasında daha etkindir (Şekil 6).

Çalışma sahasında düşme hareketi özellikle Kıradağı Bazaltı'nda ve Mare Tepesi konglomera biriminden kopan blokların düşmesi ve/veya sürüklenmesi şeklindedir. Kütle hareketlerinin özellikle Garzan (Yanarsu) Çayı'nın batı ve kuzeybatı yamaçlarında yoğunlaşth̆̆ gözlenmiştir. Buna bağlı olarak, söz konusu alanlarda bazı derelerin Garzan (Yanarsu) Çayı ile bağlantısının kısmen koptuğu ve/veya yatak değiştirdiği ve yer yer gözelerin de bu nedenle kuruduğu saptanmıştır.

Aşağı Garzan Havzası güneybatı yamaçlarındaki eğimin kuzeydoğu yamaçlara oranla daha az olmasına karşın, kütle hareketlerinin bu alanda daha yoğun olmasının en önemli nedeni jeolojik birimlerin gevşek karakterli yapısıdır. Yağışların arttı̆̆ı dönemlerde bir hazne kaya görevi gören Kıradağı bazalt örtüsü (Karadoğan, 2018) altında biriken yeralt suları ya yamaç kaynakları şeklinde yüzeye çıkmakta ya da bu yamaçlarda yüzeysel akışa geçerek yer yer heyelanlar oluşturmaktadır. Bu yapısal özelliği nedeniyle Kıradağı kuzeydoğu yamaçlarında geniş alanları etkileyen kütle hareketleri ve bu hareketin oluşturduğu yüzey şekilleri oldukça çeşitlidir. Kıradağı kuzeydoğu yamaçlarında çok sık meydana gelen kütle hareketleri sonucunda kopan malzeme oldukça uzaklara taşınmıştır. Bu taşınmanın çalışma sahasındaki en iyi örneklerine Tepecik Köyü civarında rastlanır. Söz konusu alanda Kıradağı'ndan kopan bazalt bloklar Garzan (Yanarsu) Çayı yamacına kadar sürüklenmiş ve birikmiştir. Bir hat halinde uzanan bu birikmelerden ikisinin önünde GÖ 5000-4000 yılları arasında iskân edilen Gre Şavo ve Gre Keleke yerleşmeleri belirlenmiştir ( Erim-Özdoğan \& Sarıaltun, 2011). Bu bağlamda bazalt blokların kopma ve sürüklenmesi sonucu Garzan (Yanarsu) Çayı akarsu taraçası üzerinde birikmesi en azından günümüzden 5000 yıllarından önce gerçekleşmiş bir kütle hareketinin göstergesidir. Ayrıca Kışlacık Köyü çevresinde çok geniş bir alanda heyelan aynaları görülmektedir Killi birimlerde oluşan heyelan olaylarının sık görüldüğü alanlardan bir diğeri de Sumaki Höyük ve çevresidir. Günümüzden önce yaklaşık $9000-8000$ yılları arasında iskân edilmiş Sumaki Höyük yerleşmesi kültür katlarında ikisi çok belirgin olmakla birlikte birçok sel/taşkın/toprak akması izi saptanmıştır. Bu dış etkenler nedeniyle yerleşme aralıklarla terk edilmiştir. Ayrıca bu yerleşme çevresindeki jeomorfolojik incelemelerde çok yeni heyelan izleri de tespit edilmiştir. (Sarialtun, 2019).

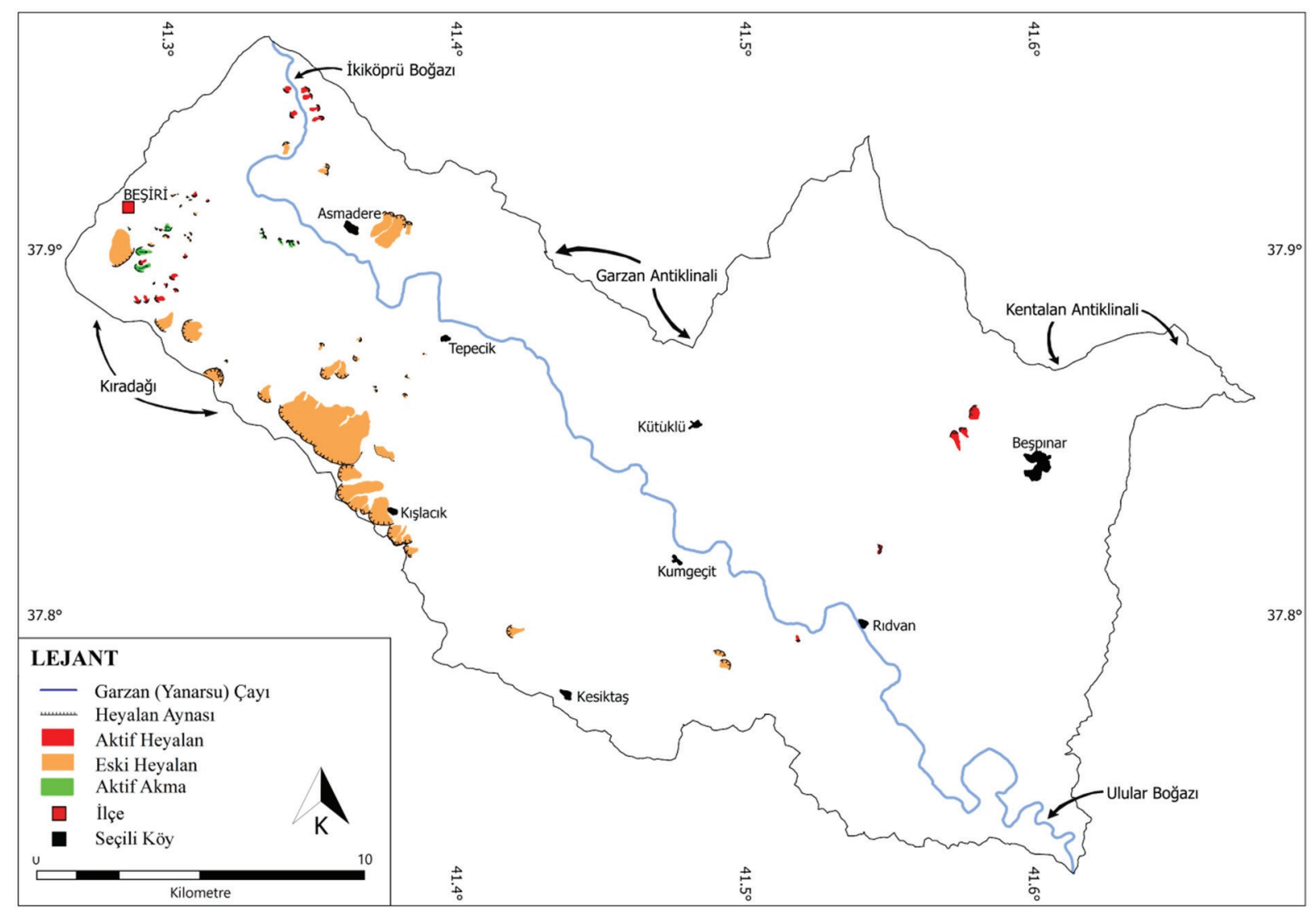

Şekil 6. Aşağı Garzan Havzası kütle hareketleri ve heyelan alanlarının dağııımı gösteren harita (Duman vd., 2009, MTA Yerbilimleri Harita Görüntüleyici ve Çizim Editörü yararlanılmış, saha çalışmalarında saptanan veriler de eklenmiştir).

Figure 6. Map showing the lower Garzan Basin mass movements and distribution of landslide areas (Created using from Duman et al., 2009, MTA Geosciences Map Viewer and Drawing Editor and the data determined during the field studies were also added). 


\subsection{Jeomorfolojik Özellikleri}

Yukarı Dicle Havzası'nda yer alan Aşağı Garzan Havzası; batıda Kıradağı ve Raman Dağı, doğuda Garzan ve Kentalan antiklinalleriyle çevrelenir. Garzan Antiklinali'nin en yüksek noktası Maharakeri Tepe 1067 metre ve Kentalan Antiklinali'nin en yüksek noktası Güneydilek Tepe 1531 metredir. Garzan ve Kentalan antiklinallerinin güneybatı yamaçlarında özellikle fay façetaları, ötelenmiş sırtlar ve vadiler, fay basamakları, birikinti yelpazeleri ve dağ eteği ovaları (piedmont) gibi fay topoğrafyasına özgü şekiller gelişmiştir. Kentalan zirveleri, aynı zamanda, Aşağı Garzan Havzası ile Başur ve Bothan Çayı havzalarının su bölümü çizgisini oluşturur.

Aşağı Garzan Havzası'nın en alçak yeri, Garzan (Yanarsu) Çayı'nın Dicle Nehri'ne kavuştuğu yerde 446 m, en yüksek yeri ise Kentalan Antiklinali üzerindeki 1531 m yüksekliğindeki Güneydilek Tepe'dir. Bu bağlamda vadi çevresinde nispi yükselti 1085 metredir. Bu durum aşındırmanın ve derine kazımanın şiddetini açıkça göstermenin yanı sıra tektonik yükselmenin etkisini de vurgular. Vadinin her iki yamacında litoloji tamamen farklıdır. Doğu-kuzeydoğu yamaçlarda kireçtaşı formasyonları, batt-güneybatı yamaçlarda ise daha çok Üst Miyosen yaşlı killi-çakıllı formasyonlar hâkimdir. Dolayısıyla yamaç işlemesi, yüzey suyu, yeralt suyu ve bitki örtüsü her iki yamaçta farklı fiziki oluşumlar sergiler.

Aşağı Garzan Havzası güncel yer şekillerinin oluşması polisiklik ile polijenik bir sürecin sonucudur. Güncel yer şekillerinin oluşma süreci, yaklaşık Üst Miyosen'den bu yana gerçekleşen karasal sürecin bir sonucudur. Aşağı Garzan Havzası izdüşümsel olarak $426,8 \mathrm{~km}^{2}$, topografik özellikleri dikkate alındığında; yaklaşık $433 \mathrm{~km}^{2}$ alana sahiptir. Ortalama yükseltisi $697 \mathrm{~m}$ olan Aşağı Garzan Havzası'nın en geniş alanını 446-646m'lik $(\% 21,8)$ yükselti basamağı oluşturur.

Aşağı Garzan Havzası bir akarsu vadisi olması itibariyle flüvyal jeomorfolojinin her türlü gelişim izlerini ve yapılarını bünyesinde barındırır. Ancak flüvyal aşındırma ve biriktirme faaliyetleriyle, aktif tektonik karşııklı bir mücadele içindedir. Beşiri ilçesi ve İkiköprü Boğazı çevresinde GB'dan KD'ya doğru alçalan ve devamında Garzan Antiklinali ile son bulan asimetrik antesedant boğaz ve tabanlı vadi sistemi vardır. Aşağı Garzan Havzası'nda KB-GD uzanışlı vadi tabanının KD kesiminde birden çok dik yamaçlara geçilir. Bu yamaçların varlığı, Garzan Antiklinali altına bindirme (ters fay) ile sokulan tektonik yapı ile açıklanabilir. Vadi enine profili, Gedikler ile Kumçay köyleri arasında daralmakta; ama daha güneye gidildiğinde, Garzan Antiklinali'nin bitişi nedeniyle Kentalan Antiklinali'ne kadar genişlemektedir. Kumgeçit Köyü güneyinde vadi asimetrisi tam tersine döner. Eğim özelliklerine de yansıyan topografik değişim tektonizmanın kontrolünde şekillenmiştir. Aşağı Garzan Havzası'nda; düzlükler $(\% 0 \leq 5) \% 18,27$, yamaçlar $(\% 5 \leq 20) \% 40,58$ ve dik yamaçlar (\%+20) \%41,15 alan kaplar. Bu bağlamda eğim özelliklerine göre; düzlüklerin az, yamaç ve çok dik yamaçların \%80'den fazla alan kapladığı bir havza özelliği taşımaktadır.

Garzan (Yanarsu) Çayı Havzası'nın inceleme alanında kalan aşağı bölümünde oldukça geniş alanlara yayılan akarsu taraçaları saptanmıştır. Bu akarsu taraçalarının oluşum süreci açısından Dicle Nehri akarsu taraçalarıyla belirgin bir ilişkisi de söz konusudur. Bununla birlikte gerek bu çalışmada gerekse diğer jeomorfolojik çalışmalarda Dicle Nehri'nin özellikle akarsu taraçaları konusunda tüm kollarıyla birlikte genelini ele alan bir çalışma henüz gerçekleştirilmemiştir. Kuzucuoğlu (2002) ve Doğan (2005) yaptıkları çalışmalarla Dicle Nehri'nin, özellikle Bismil ile Batman Çayı arasında kalan bölümündeki akarsu taraçaları ayrıntılandırmışlardır. Illuh Deresi jeomorfoloji çaIışmasında ise Batman Çayı akarsu taraçaları tanımlanmıştır (Sunkar \& Tonbul, 2012). Yıldırım ve Karadoğan'ın çalışmalarında (Yıldırım \& Karadoğan, 2005) Hasankeyf ve çevresindeki aşınım ve birikim alanları belirlenerek yorumlanmıştır. Aşağı Garzan Havzası tanımı yapılan bir diğer çalışmada ise aşınım ve birikim seviyeleri dikkate alınarak; T1-T5 taraçaları şeklinde ifade edilmiştir. (Polat, 2018; Sunkar \& Polat, 2018) Her ne kadar bu çalışmalarda "Aşağı Garzan Havzası" adlandırması kullanılmış olsa da gömük menderes vadi yapısına sahip ikiköprü Boğazı'nın kuzeyi ile güneyini neden birlikte değerlendirdikleri açık değildir. İkiköprü Boğazı'nın kuzeyinden Kozluk ilçesine kadar Garzan (Yanarsu) Çayı'nın nehir akış yönü, yatak tipi, örgülenme ve vadi yapısı İkiköprü Boğazı'nın güneyinden farklıdır. Ayrıca söz konusu çalışmalarda taraçaların istifleri ve yayılım alanları detaylarıyla tanımlanmamış ve yayılım alanları haritalandırılmamıştır. Bununla birlikte Polat (2018) T4 ve T5 taraçalarının özelliklerinden hiç bahsetmemektedir. Bu çalışmada ise yukarıda sınırları tanımlanan Aşağı Garzan Havzası akarsu taraçaları ayrıntılarıyla incelenmiş ve haritalandırılmıştır. Böylece Yukarı Dicle Havzası akarsu taraçalarının bir eksiği kısmen de olsa tamamlanmaya çalışılmıştır.

İkiköprü ve Ulular boğazları arasında belirginleşen akarsu taraçaları 25,7 km²'lik alanı ile araştırma alanımızın \%6'sını oluşturur. Aşağı Garzan Havzası'nda dört akarsu taraça seviyesi belirlenmiştir. $+30-40 m$ yükseltide yer alan akarsu taraçaları (GT1), +10-20 m (GT2), +5-9 m (GT3) ve +1-4 m (GT4) olarak adlandırılmıştır. Akarsu taraçaları sırasıyla: GT 1:0,8 km², GT2: 8,2 km², GT3: 9,5 km² ve GT4: 7,2 km² bir alanı kaplar (Şekil 7-10).

Çalışma sahasındaki akarsu taraçalarının oluşumunda tektonik etkiler ile Dicle Nehri Vadisi'nin şekillenme süreci belirleyicidir. Akarsu taraçaları genellikle düzlükler $(\% 0 \leq 2)$ ve dalgalı düzlüklerden (\%2 $\leq 5)$ oluşmakla birlikte, GT1 seviyesinde eğim biraz artar. GT4 olarak tanımlanan düzlükler Garzan (Yanarsu) Çayı'nın en genç akarsu taraça seviyeleridir. Bu seviyeden sonra güncel birikmeler, mevsimlik kum tepeleri ve taşkın seviyeleri görülmektedir. Garzan (Yanarsu) Çayı talveg seviyesinden +3040 metre yükseklikler arasındaki GT1 akarsu taraçaları oldukça dar alanlarda tespit edilmiştir ve genel hatlarıyla Pliyosen yaşlı konglomera görünümünde ve aşınım yüzeylerini örten teraslar şeklinde uzanmaktadır. Garzan (Yanarsu) Çayı yamaçlarındaki ikinci teras +10-20 metre yükseklikler arasında saptanan GT2 akarsu taraçalarıdır. Bu akarsu taraçalarının, GT1 akarsu taraçalarına oranla daha geniş alanlara yayıldığı gözlemlenmiştir. Yer yer süreklilik gösteren bu akarsu taraçaları, özellikle faylı alanlarda ve dik yamaçlı kesimlerde parçalıdır. GT2 akarsu taraça birikimleri orta ve ince çakıllardan oluşur. Üçüncü akarsu taraça seviyesi olan GT3 Garzan (Yanarsu) Çayı'ndan +4-9 metre yüksekliklerde saptanmıştır. Garzan (Yanarsu) Çayı Havzası'nın birçok yerinde, özellikle son 20 yıldır yapılan pamuk ve mısır tarımı sulaması ile yoğun tarımsal faaliyetlerin yol açtı̆̆ erozyon ve arazi düzeltmesi sonucunda GT3 ve GT2 akarsu taraçaları yer yer birbirine karışmıştır. Bu nedenle, vadinin bazı kesimlerinde iki seviyeyi belirgin sınırlarla birbirlerinden ayırmak oldukça güçtür. 
GT4 akarsu taraçaları, Garzan (Yanarsu) Çayı talveg seviyesinden +1-3 metre yükseklikler arasında saptanmış en genç akarsu taraçasıdır. Genel olarak çakıl ve kumlu silt tabakalarından oluşan bu taraça dolgularında yer yer iri çakıllar ve/veya ince kum seviyeleri tespit edilmiştir. Ayrıca, farklı seviyelerde taşkın malzemesi oluşumunu işaret eden karmaşık sediment birimlerine de rastlanmıştır.

Taşkın alanları ve/veya sulak alanlar, farklı özelliklere sahip ekosistemlerde zengin habitat çeşitliliği sergiler. Bu alanların varlığı, havzanın niteliğini anlamak için büyük önem arz eder. Sulak alanlar insanlara özellikle yiyecek ile yapılarında kullanabilecekleri malzeme açısından sayısız olanak sunar (Güney, 2014). Sumaki Höyük yerleşmesi mimarisinde de kullanıldığı saptanan saz ve/veya otsu bitkiler, Aşağı Garzan Havzası'nda geniş alanlara yayılmıştır. Sazlıklar ve/veya otsu bitkilerin boyları, özellikle Gedikli ile Sulan köyleri ve çevresinde üç metreyi bulmaktadır. Bu bitkilerin günümüzdeki konar-göçer topluluklarının kışlaklarında yapı malzemesi olarak yoğun kullanıldığı arazi çalışmalarında tespit edilmiştir. Taşkın yatakları 10,3 $\mathrm{km}^{2 \prime}$ lik alanı ile araştırma alanımızın \%2,4'ünü oluşturur.

\section{Değerlendirme ve Tartışma}

Aşağı Garzan Havzası coğrafi açıdan yakın çevresine göre oldukça farklı bir coğrafik manzara sunar. Bu farklılığın yerleşme tarihi, yerleşme türü, konut ve beşerî faaliyetler üzerinde önemli etkileri vardır. Farklı tarihlerde yürütülen yüzey araştırmalarında GÖ 9000-330 tarihleri arasında iskân edilmiş toplam 22 arkeolojik yerleşim yeri saptanmıştır. Ancak GÖ.12000-8000 yılları arasını temsil eden Neolitik Dönem kültür dolgusuna sahip sadece 1 yerleşim yeri tespit edilmiştir ( Erim-Özdoğan \& Sarıaltun, 2011). Bu neolitik yerleşim yeri GÖ.9000-8000 yılları arasında iskân edilmiş olup; GÖ.12000-9000 yılları arasında iskân edilen bir erken dönem yerleşme yoktur. Bununla birlikte havzanın dış çevresinin aksine GÖ.8000-5000 yıllarına tarihlenen Halaf, Ubeid ve Uruk dönemi yerleşmeleri bulunmamaktadır. GÖ. 50002330 tarihleri arasında Aşağı Garzan Havzası yoğun olarak iskân edilmiştir. Yapılan arkeolojik araştırmaları sonucunda inceleme alanında Tunç Çağı ile Demir Çağı dönemlerine ait 21 yerleşim yeri tespit edilmiştir ( Erim-Özdoğan \& Sarıaltun, 2011).

Holosen Dönem'de havzadaki en erken iskân Sumaki Höyük yerleşmesinde görülür (Şekil 7). Bu yerleşim yeri AMS yöntemi yaşlandırmasına göre GÖ. kal. $9084 \pm 57$ - 8123 \pm 50 yılları arasında tarihlendirilmiştir (Sarıaltun, 2019). Bu yerleşmenin morfometrik verileri sabit alınarak CBS ortamında elde edilen formüller ile yapılan uygunluk analizine göre Aşağı Garzan Havzası'nda söz konusu yerleşmeyle aynı özelliklere sahip 1428,50 ha bir alan belirlenmiştir. Uygunluk analizi sonucunda Asmadere Köyü, Samanlı ve Yalınkavak köyleri ile Ortaalan Köyü çevresindeki geniş alanların Sumaki Höyük fiziki ortamıyla benzer niteliklerde olmasına ve havza dışında çokça Neolitik yerleşim yeri saptanmış (Benedict, 1980) olmasına karşın Sumaki Höyük'le çağdaş yerleşim yeri yüzey araştırmasında tespit edilmemiştir ( Erim-Özdoğan \& Sarıaltun, 2011).

Neolitik Döneme tarihlendirilen ve havzaya en yakın yerleşim yeri Aşağı Garzan Havzası'nın hemen güneydoğu dış sınırında yer alan Aingerm (Benedict, 1980) yerleşmesidir. Söz konusu dönem için havzanın bu kadar boş kalması kültürel tercihlerden çok havzanın özellikle Holosen Dönemi'ndeki fiziki ortamın dinamik değişkenliğiyle ilişkili gibidir. Sumaki Höyük'te özellikle N4 ve N2 evrelerinin üzerindeki sel/taşkın istifleri ( Erim-Özdoğan \& Sarıaltun, 2011; Sarıaltun, 2019) ve Çemialo Sırt OTÇ tabakasını örten kızılkahverengi alüvyol dolgu (Erim Özdoğan ve Gündüzalp, 2018) ile Gre Amer Höyüğü iTÇ tabakasını örten çakıllı-kumlu dolgular (Pulman ve Blaylock, 2018) ve Ortaçağ’a tarihlendirilen Kani Kervana yerleşmesi üzerinde-

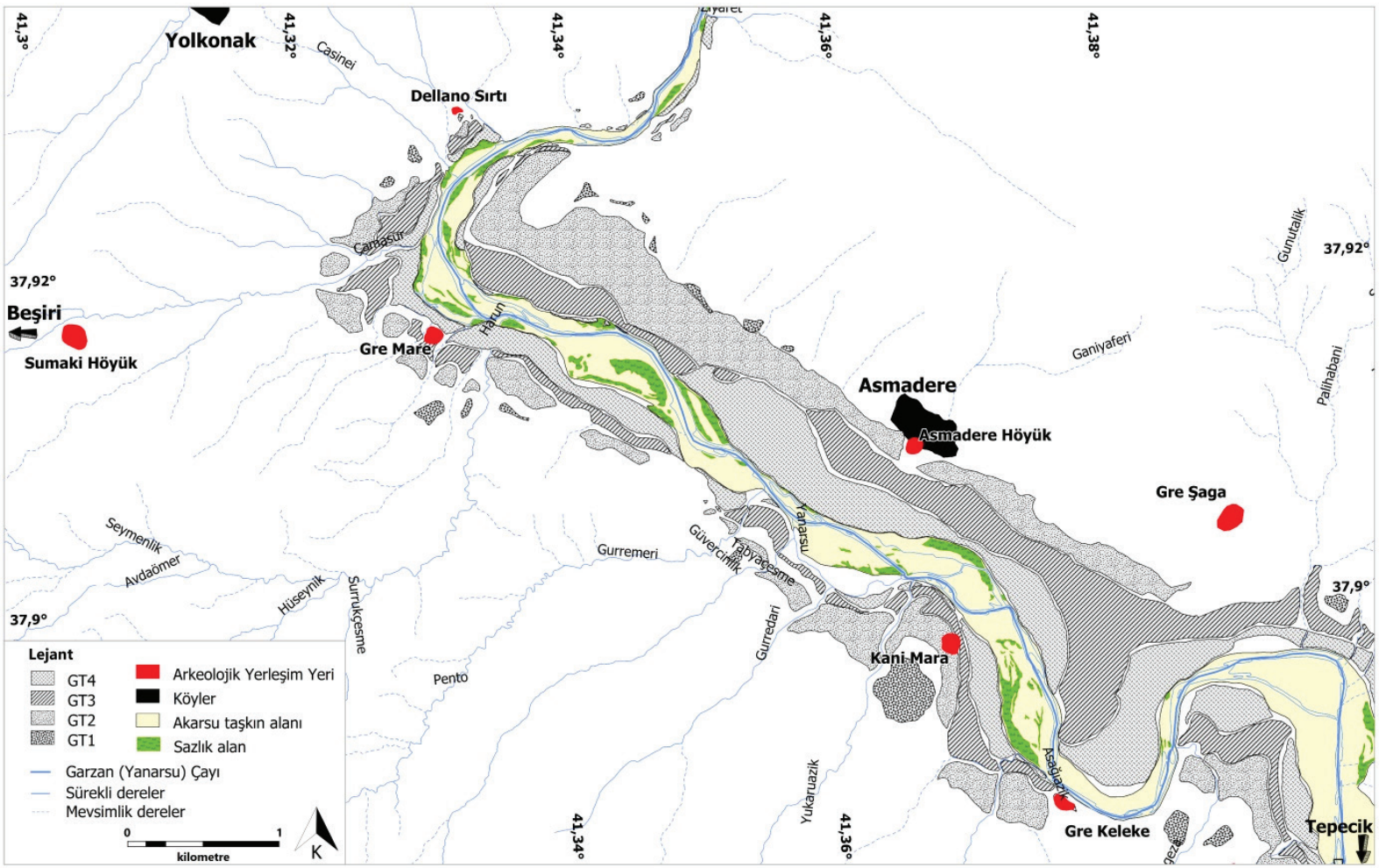

Şekil 7. Aşağı Garzan Havzası'nın Beşiri ilçesi ile Tepecik Köyü arasında kalan kısmının jeomorfolojisini ve arkeolojik yerleşim yerlerinin konumunu gösteren harita.

Figure 7. Map showing the geomorphology of the lower Garzan Basin between between Beşiri district and Tepecik Village and the location of the archaeological settlements. 
ki $40 \mathrm{~cm}$ alüvyon örtü düşünüldüğünde Aşağı Garzan Havzası'nda birçok yerleşme sel/taşkın veya yüzeysel akmaların altında kaldığı ileri sürülebilir. Buna benzer bir durum Kalkolitik Dönem yerleşmeleri için de geçerli olması çok muhtemeldir. Buna karşın bir başka olasılık ise; Sumaki Höyük yerleşmesinde de açıkça belirlendiği üzere (Sarıaltun, 2019) sel veya taşkınların GÖ.5000 yıllarına kadar havzada etkin olduğu ve bu dönemde yaşayan topluluklar tarafindan yerleşmeye uygun güvenli bir alan olarak görülmediği ileri sürülebilir.

Havzada yürütülen arkeolojik yüzey araştırmalarında saptanan Illk Tunç Çağ (iTÇ) yerleşmelerinin dördü Garzan (Yanarsu) Çayı́nın sağ yamacında ve diğer dördü de sol yamacındadır (Şekil 7-10). Söz konusu bu yerleşmelerin büyük bir kısmı havzanın kuzey kesiminde yer alır. Bu alan Samanlı-Yazıhan köyleri arasında Şelmo Formasyonu'nun geniş alanlarda yayılım gösterdiği ve akarsu taraçalarının da geniş alanları kapladığı tarımsal potansiyelin yüksek olduğu kesimdir. Sumaki Höyük güneyinde ve Kışlacık Köyü çevresindeki heyelan alanları ile havzanın güneyinde Germik Formasyonu'nun yayılım gösterdiği alan ile parçalı topografik özelliklere sahip ve Garzan (Yanarsu) Çayı'ndan oldukça uzak olan Beşpınar ve Ortaalan köyleri arasında iTÇ yerleşmeleri saptanmamıştir.

ITÇ yerleşim yerleri genellikle Garzan (Yanarsu) Çayı kenarında, 485-619 m arasındaki yükseltilerdedir. Bu döneme ait yerleşmeler \%2,83 ile \%24,92 arasında değişen oldukça farklı eğime sahip alanlara konumlanmıştır. Bununla birlikte sekiz yerleşim yerinden beşinin eğim \%10-15 arasındadır. Gre Şaga yerleşim yeri dışındaki yedi yerleşim yeri Garzan (Yanarsu) Çayı'ndan 53,34 - 53,79 m uzaklıktadır (Şekil 7-10). Gre Şaga yerleşim yeri ise; Garzan (Yanarsu) Çayı'na 892,07 m uzaklıkta olup, yükselti değerleri $(619 \mathrm{~m})$ açısından da diğer iTÇ yerleşim yerlerinden farklı özelliktedir (Şekil 7) Diğer yedi yerleşim yeri ise; 485 - 542 m yükseklikleri arasındadır.
Ayrıca, bu yedi yerleşim yerinden altısı Garzan (Yanarsu) Çayı güncel seviyesinden $+3-14 \mathrm{~m}$ yükselti farkındaki tepelik alan ve/veya akarsu taraçaları üzerine konumlanmasına karşın Şevlend Tepe $+34 \mathrm{~m}$ ve Gre Şaga $+88 \mathrm{~m}$ yükselti farkına sahip tepelik alanlar üzerine konumlanmıştır (Şekil 7, 9) Bu anlamıyla bu iki yerleşmenin diğer iTÇ yerleşmelerinden farklı bir işleve sahip olması muhtemeldir. Her iki yerleşmede de arkeolojik kazı çalışması yapılmadığından dolayı sosyal örgütlenme modeli ve yerleşim stratejisi dair önermeler yapmak oldukça güçtür. Umarım ileriki yıllarda söz konusu yerleşmelerin arkeolojik kazıları yapılabilir ve böylece yerleşim stratejisi açısından karşılaştırma olanağı elde edebiliriz.

ITÇ yerleşim yerleri ve yakın çevresinin morfometrik verileri dikkate alınarak CBS ortamında elde edilen formüller ile yapılan uygunluk analizine göre Aşağı Garzan Havzası'nda söz konusu yerleşmelerle aynı özelliklere sahip 508,10 ha bir alan belirlenmiştir (Şekil 12). CBS ortamında yapılan uygunluk analizi sonucunda özellikle İkiköprü Boğazı ile Rıdvan-Ikiyaka köyleri arasındaki alanın diğer alanlarda tespit edilen iTç yerleşmeleri fiziki ortamıyla benzer morfometrik özelliklere sahip olmasına karşın; sözü edilen kesimde bu dönemi temsil eden bir yerleşim yeri saptanmamıştır. Rıdvan-ikiyaka köyleri arasında gerek tarıma elverişli alanların geniş alanlara yayılması gerekse sulak alanların Aşağı Garzan Havzası'nda en fazla yayılım gösterdiği bölge olmasına karşın İlk Tunç Çağ toplulukları tarafindan kullanılmamıştır (Şekil 10). Fiziki ortam koşullarının çoğunun uygun olduğu bu alanın tercih edilmeme nedenini farklı bir unsurda aramak gerekir. Söz konusu alanda Garzan (Yanarsu) Çayı'nın sağ yamacında Germik Formasyonu kireçli fasiyesi yüzeylenirken, sol yamacında Şelmo Formasyonu ile Lahti Formasyonu çakıllı birimleri yüzeylenmektedir. Ayrıca bu alan güncel köy yerleşmelerinin de sıklıkla kullandığı önemli yerleşim alanlarından biridir. Söz konusu verimli alan, sulak alanların yoğunluğu ve dolayısıyla saz benzeri yapı malzemesinin bolluğu ile birlikte hayvan otlatmak

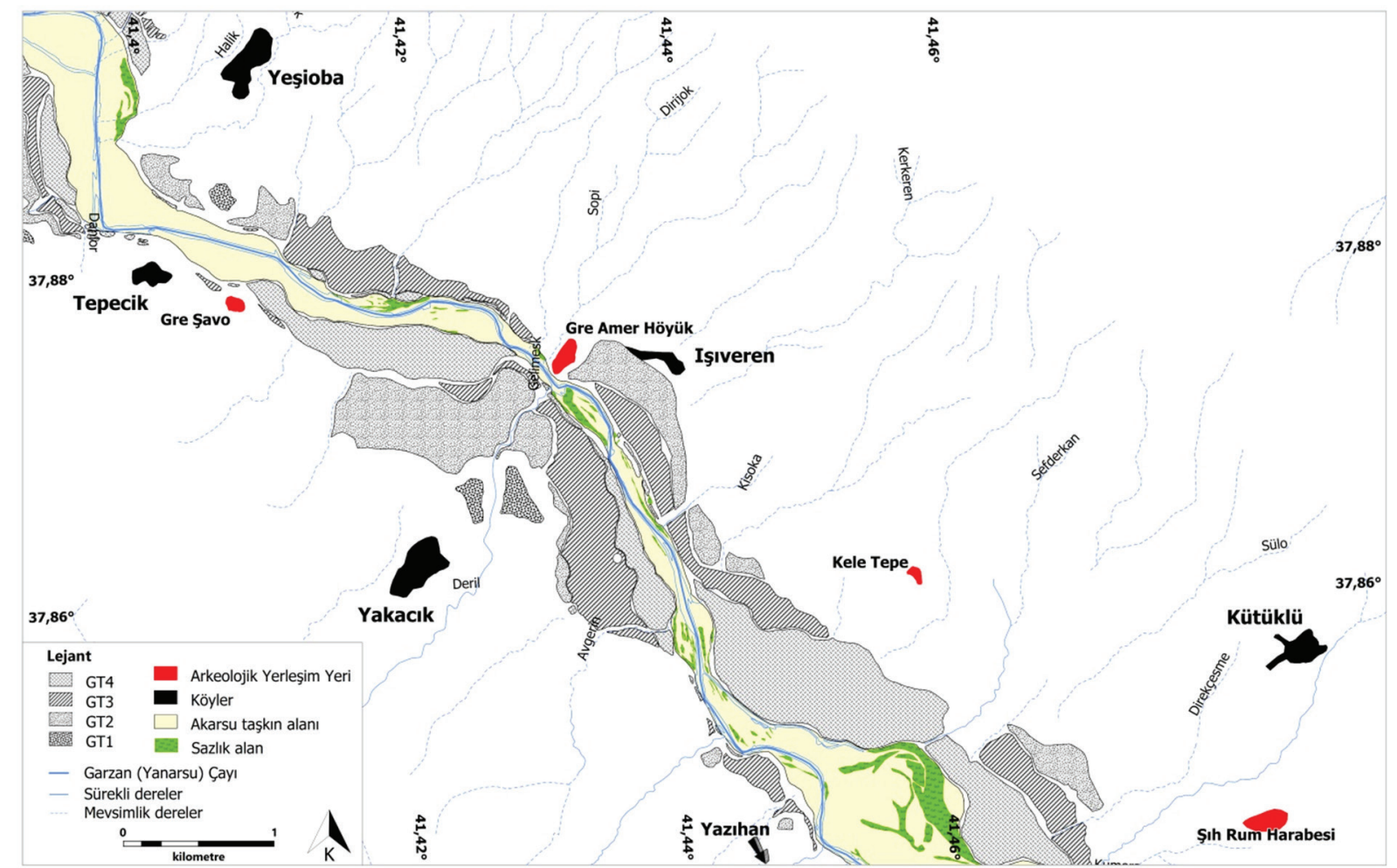

Şekil 8. Aşağı Garzan Havzası'nın Tepecik ile Yazıhan köyleri arasında kalan kısmının jeomorfolojisini ve arkeolojik yerleşim yerlerinin konumunu gösteren harita. Figure 8. Map showing the geomorphology of the lower Garzan Basin between Tepecik and Yazıhan villages and the location of the archaeological settlements. 


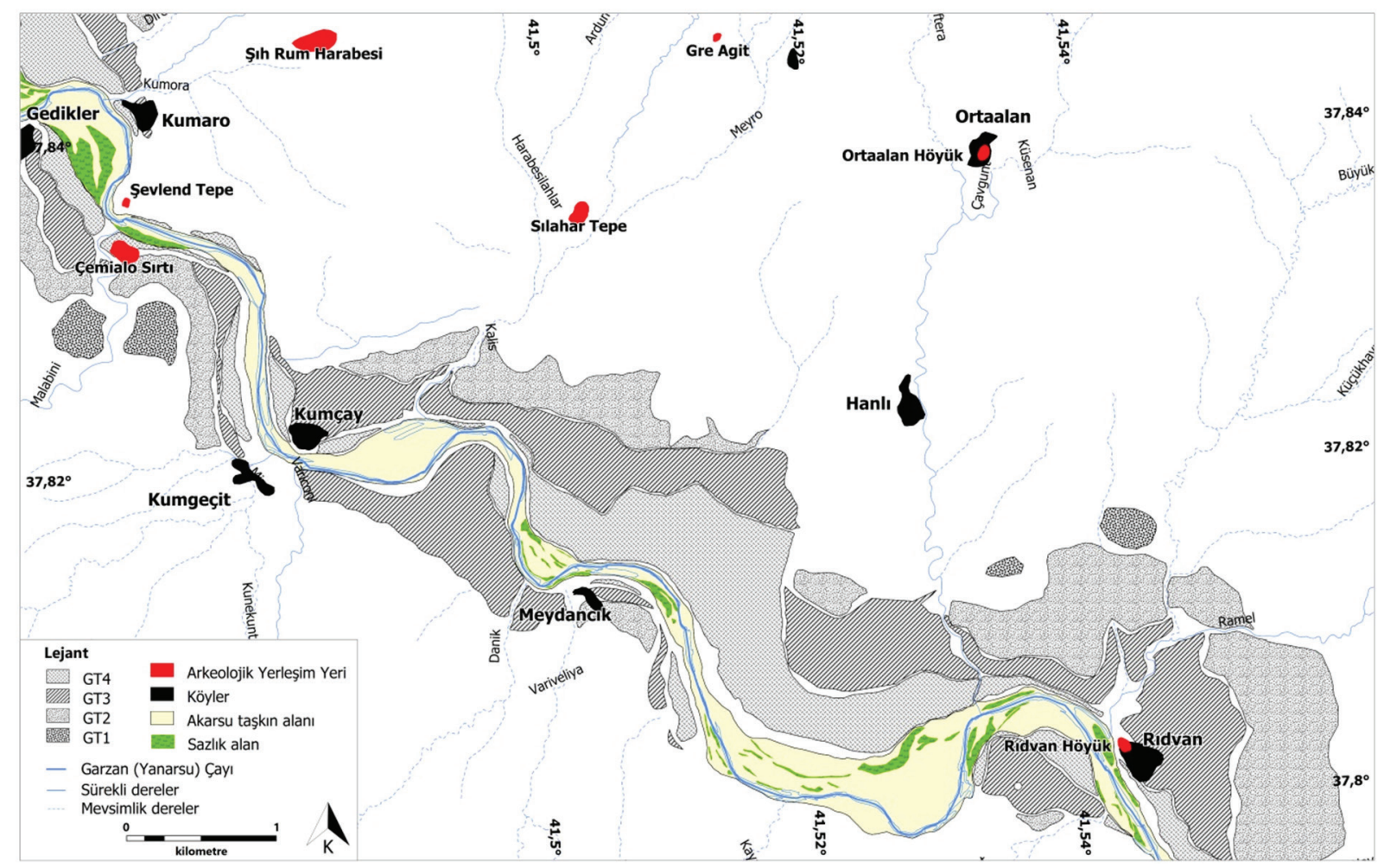

Şekil 9. Aşağı Garzan Havzası’nın Yazıhan (Gedikler Mah.) ile Rıdvan köyleri arasında kalan kısmının jeomorfolojisini ve arkeolojik yerleşim yerlerinin konumunu gösteren harita.

Figure 9. Map showing the geomorphology of the lower Garzan Basin between Yazıhan (Gedikler Mah.) and Rıdvan villages and the location of the archaeological settlements.

için meraların geniş alanlarda görülmesi nedeniyle yarı-göçebe gruplar tarafindan yoğun olarak kullanılmaktadır. Sözü edilen bölgede Sulan, Başarı, Rıdvan ve Çakıllı köyleri ile Sulan Kom, Sulane Girgiz Kom ve Çemistrin Kom kışlakları bulunmaktadır. Tüm bunlar birlikte düşünüldügünde iTÇ yerleşim yeri seçim kriterleri ve stratejisi açısından farklı denklemlerin söz konusu olduğu ileri sürülebilir. Ancak havzada bulunan sekiz yerleşim yerinden en azından altısının (Gre Şaga ile Şevlend Tepe hariç) tercih edilmesinde savunma önceliğinin yerleşim yeri seçiminde bir tercih nedeni olmadığı aşikârdır. Keza sözü edilen bu alt yerleşmenin tamamı saldırıya açık ve çevresinde doğal koruma alanı bulunmayan yerleşmelerdir. Ayrıca bu alt yerleşmenin çevresinde inşa edilmiş koruma duvarı veya sur benzeri mimari öğeden gerek yüzey araştrrmalarında (Algaze vd., 1991; Erim-Özdoğan \& Sarıaltun, 2011) gerekse Çemialo Sırtı(Erim Özdoğan \& Gündüzalp, 2018) ile Gre Amer Höyük kazı yayınlarında (Pulman \& Blaylock, 2018) söz edilmemektedir.

MÖ. 2. Bin yıla tarihlenen Orta Tunç Çağı'na (OTÇ) geldiğimizde yerleşim stratejisi ve alan kullanımında bir önceki döneme göre çok az farklılık göze çarpmaktadır. Bu farklılıkların oluşmasında hem yerleşim yeri sayısındaki artş̧ hem de bir önceki döneme göre farklı fiziki ortamlarda iskân alanlarının saptanmış olmasıdır (Şekil 9) Yerleşim yerlerinin konumlandığı yükselti basamaklarında bir önceki dönemle kıyaslandığında belirgin bir farklılık görülmemektedir. OTÇ dönemi ile birlikte havzayı yaşam alanı olarak kullanan topluluklar, Garzan (Yanarsu) Çayı́ndan daha uzak mesafeleri de iskân yeri olarak kullanmaya başlarlar. Yüzey araştırmalarında saptanan toplam 13 OTÇ kültür dönemi yerleşim yerleri, Garzan (Yanarsu) Çayı'na 53,34 3533,87 m uzaklıklardadır (Şekil 7-10). Bir önceki dönem olan iTÇ'da yaşam alanı olarak kullanılmamış olan Ortaalan Höyük, Silahar Tepe ve Asmadere Höyük gibi "yeni" yerleşim yerleri Garzan (Yanarsu) Çayı'ndan 585,90 - 3533,87 m uzaklıklardadır
(Şekil 11) OTÇ yerleşmeleri 485-542 m arasında olup büyük bir kısmı 530 - 590 m yüksekliklere sahiptir. OTÇ dönemiyle birlikte Aşağı Garzan Havzası'nda yerleşim yoğunluğu iki faklı alanda yoğunlaşmış gibidir. Bunlardan sadece biri iTç yerleşmelerine benzer şekilde havzanın kuzey kesiminde diğerleri ise havzanın orta bölümündedir. Ayrıca ITÇ yerleşim dağılımına benzer bir şekilde OTÇ yerleşim dağılımında da havzanın güneyi (Ulular Köyü çevresi) kullanılmamıştır.

MÖ. 1.Bin yıla tarihlenen Demir Çağı'nda (DÇ) yerleşim stratejisi ve alan kullanımında bir önceki dönemlere oranla havza kültürel açıdan çok faklı bir görünüme bürünmüştür. Kentalan Antiklinali'nin bat yamaçları hariç havzanın hemen hemen tamamında Demir Çağı kültür dolgusuna sahip yerleşim yeri görülmektedir. Yüzey araştırmalarında saptanan toplam 21 DÇ yerleşim yeri Garzan (Yanarsu) Çayı'na 51,23 - 3533,87m uzaklıklardadır. ITÇ ve OTÇ yerleşimleri dışında ilk defa DÇ döneminde tercih edilen yerleşimler ise Garzan (Yanarsu) Çayı'na 51,23 - 2990,87m uzaklıklardadır. Söz konu bu yerleşim yerlerinin birçoğu daha önceki dönemlerin aksine artık havzanın güney kesiminde de (Ulular Köyü çevresi) görülmektedir (Şekil 10).

Yüzey araştırmalarında belirlenen Demir Çağ kültür dolgusuna sahip yerleşim yerlerinin dokuzu Garzan (Yanarsu) Çayı́nın sağ yamacında ve diğer on ikisi de sol yamacında yer alır. DÇ yerleşim yerleri \%2,83 ile \%24,92 arasında değişen oldukça farklı eğimli alanlara konumlanmıştir. Bununla birlikte yirmi bir yerleşim yerinden sadece üçü \%2-5 eğim değerindeki alanlara konumlanmıştrr. Demir Çağı'ndan itibaren yerleşim yeri seçiminde Garzan (Yanarsu) Çayı'na yakınlık önemsenmemiş gibidir. Saptanan yirmi bir yerleşim yerinden sadece beşi Garzan (Yanarsu) Çayı'na 100 metreden daha yakın mesafededir. DÇ yerleşmeleri konumlandığı alanların yükseklikleri 475 - 623 m arasında olup büyük bir kısmı 530 - 587 m yüksekliklerde konumlanmıştır. Ayrıca söz 


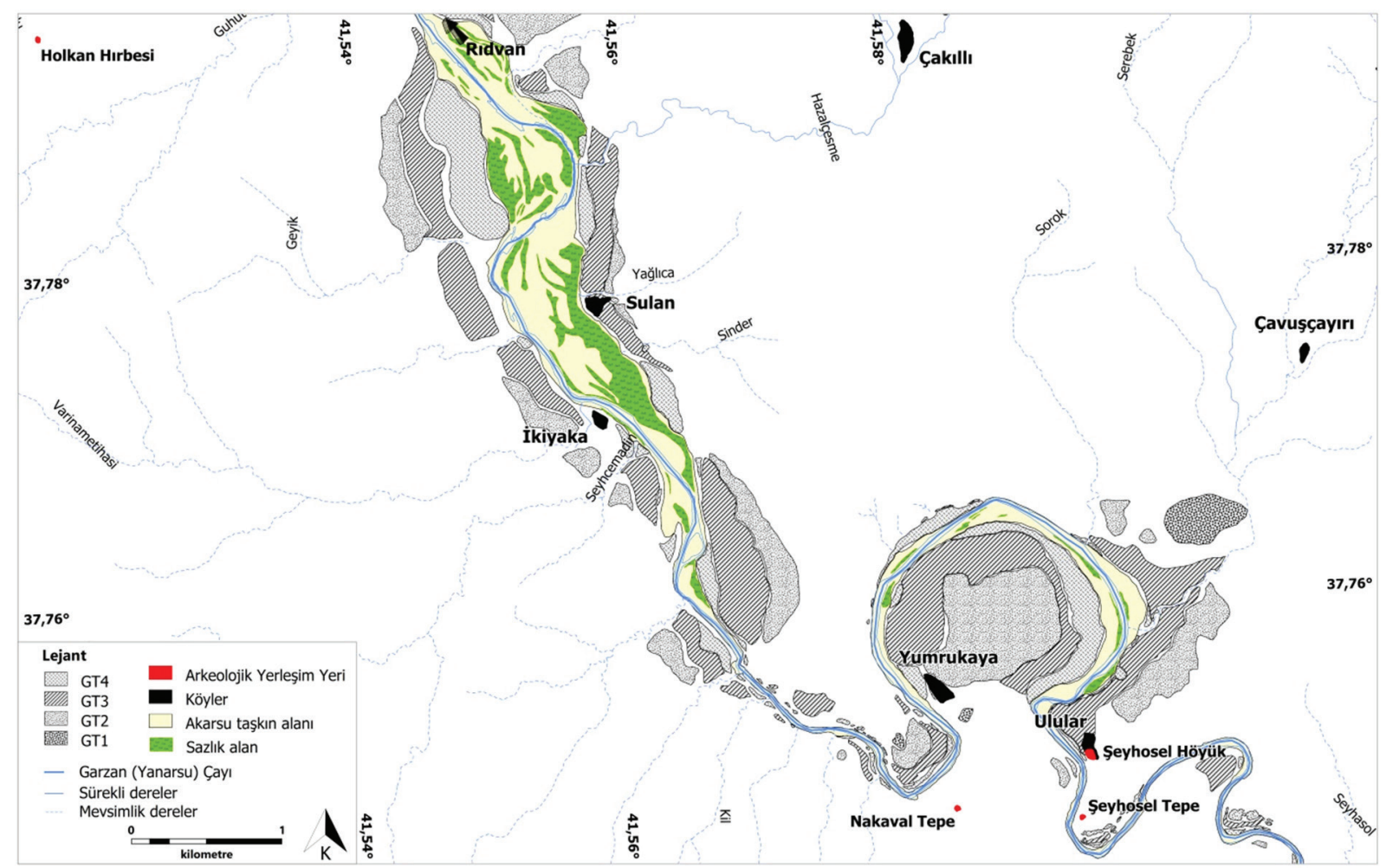

Şekil 10. Aşağı Garzan Havzası'nın Rıdvan ile Ulular köyleri arasında kalan kısmının jeomorfolojisini ve arkeolojik yerleşim yerlerinin konumunu gösteren harita. Figure 10. Map showing the geomorphology of the lower Garzan Basin between Rıdvan and Ulular villages and the location of the archaeological settlements.

konusu bu yerleşmelerden on beşi Garzan (Yanarsu) Çayı güncel yükseltisinden +14-128 m yükselti farkına sahip tepelik alan üzerine ya da yamaçlardadır (Şekil 7-10). Bu anlamıyla DÇ yerleşim yerlerinin çoğu gerek iTç gerekse OTÇ yerleşmelerinden farklı bir işleve ya da sosyal örgütleme modeline sahip gibidir.
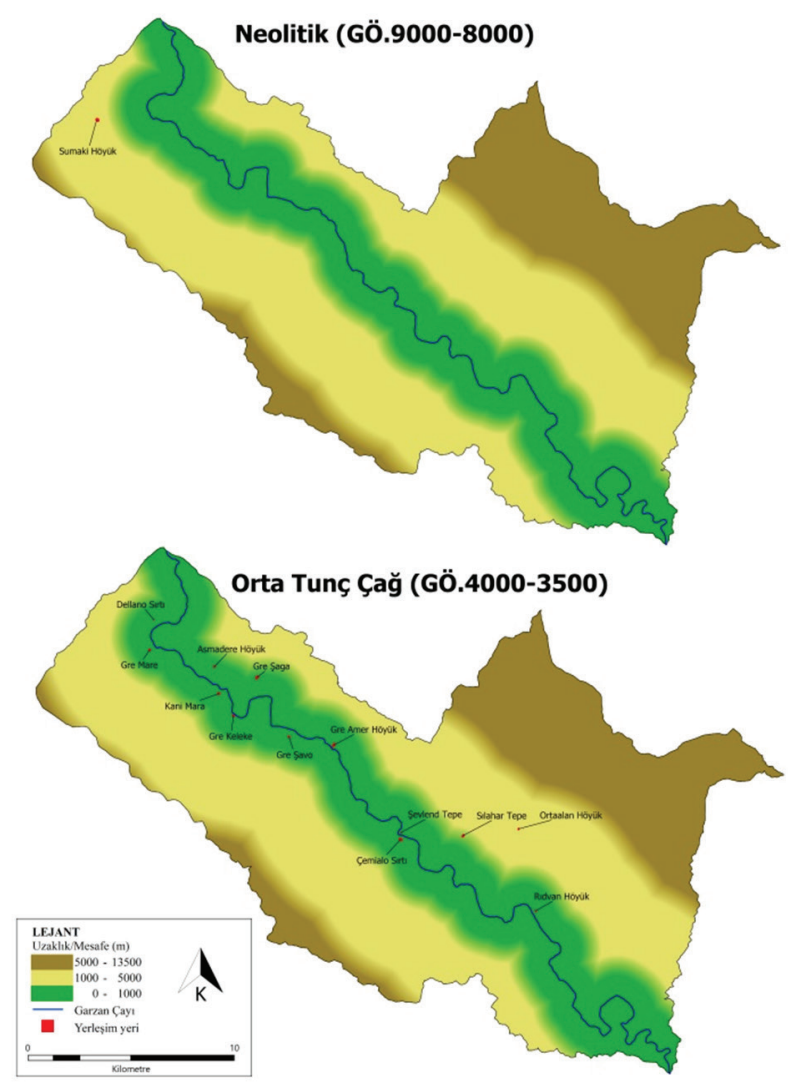

DÇ yerleşim yerleri ve yakın çevresinin morfometrik verileri sabit alınarak CBS ortamında elde edilen formüller ile yapılan uygunluk analizine göre Aşağı Garzan Havzası'nda Demir Çağ yerleşmeleriyle aynı özelliklere sahip 3706,15 ha oldukça geniş bir alan belirlenmiştir (Şekil 12). Diğer dönemlere kıyasla bu kadar geniş alanların DÇ yerleşim yerleri için uygun olarak
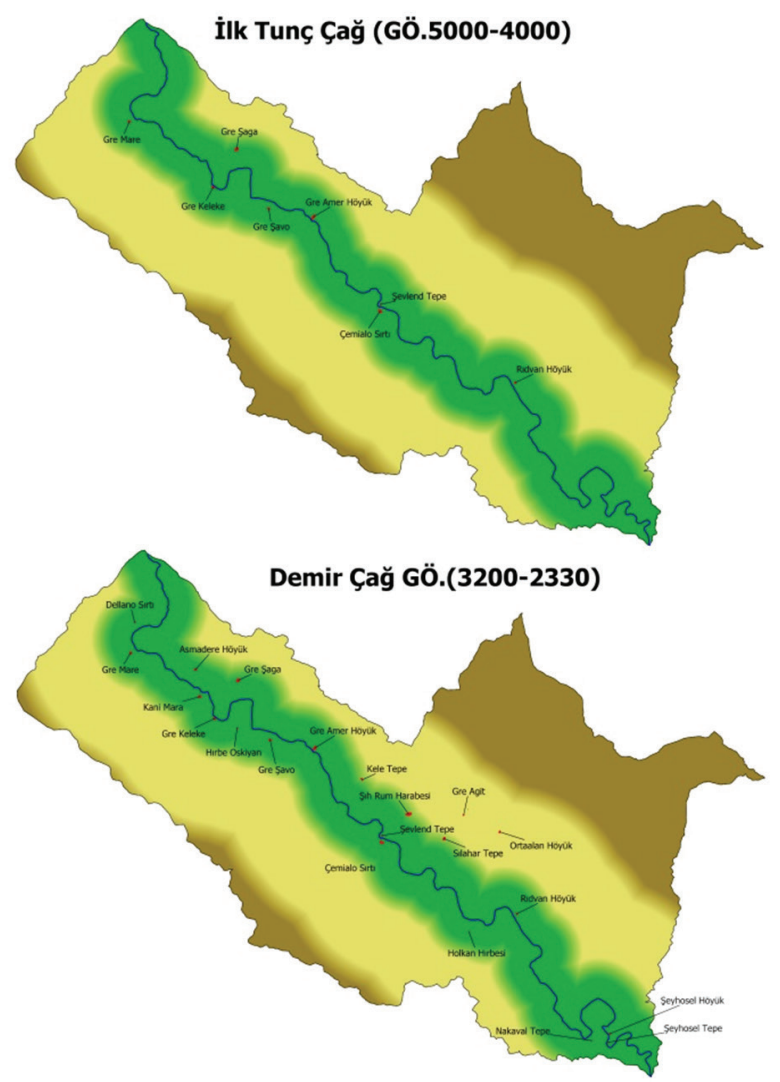

Şekil 11. Arkeolojik yerleşim yerlerinin Garzan (Yanarsu) Çayı'na uzaklıkları gösteren sayısalaştrılmış arazi modeli haritası.

Figure 11. Digitized terrain model map showing the distances of archaeological settlements to the Garzan Stream. 


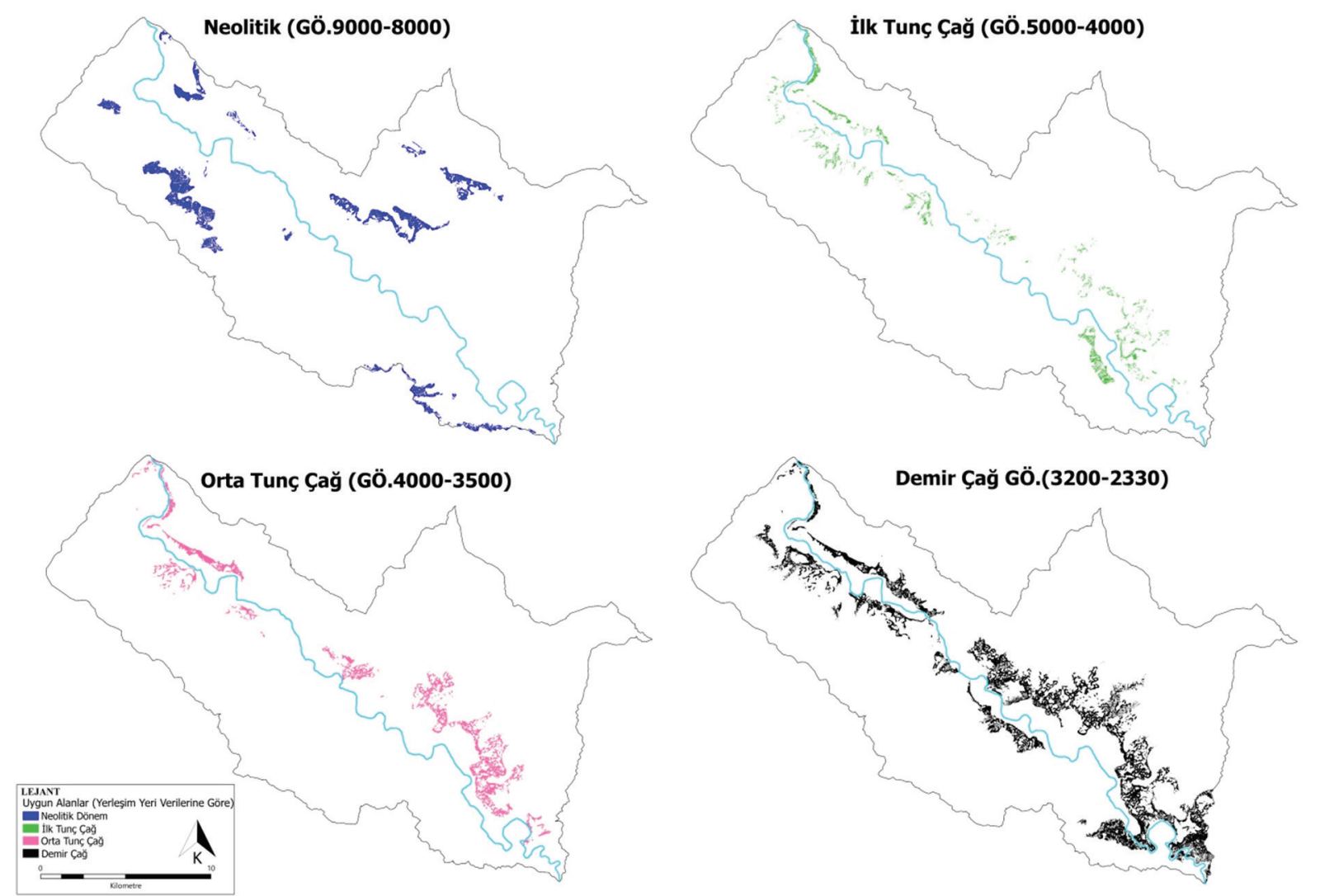

Şekil 12. Aşağı Garzan Havzası'ndaki arkeolojik yerleşim yerleri morfometrik verilerine göre uygunluk analiz modeli haritaları.

Figure 12. Correspondence analysis model maps according to morphometric data of archaeological settlements in the Lower Garzan Basin.

ortaya çıkmasının en temel nedeni, bu döneme tarihlenen yerleşim yerlerinin yükseklik, eğim, nehre yakınlık gibi farklı niteliklerdeki alanlara konumlanmasıdır. Dolayısıyla önceki dönemlere kıyasla Demir Çağ'da havzayı iskân eden toplulukların yaşam stratejisi ve sosyo-ekonomisi farklıdır. Havzada tespit edilen DÇ yerleşim yerlerinin ortak morfometrik özellikleri dikkate alınacak olursa Kentalan Antiklinali batı yamaçları ile Kışlacık Köyü çevresindeki heyelan bölgesi hariç havzanın hemen hemen tamamına yayılmıştır.

\section{Sonuç}

Bir yerleşim yeri bağlamında mekân toplulukların değerlerini ve tasarımlarını şekillendirdiği ya da farklılaştırdığı gibi insan da mekânı biçimlendirir. Yerleşik ya da geçici yaşam alanı olarak bir yerleşim yerinin tercih edilmesindeki etkenlerin başında, her ne kadar fiziki ortam gelse de fiziki ortam da zaman içinde topluluklar tarafindan şekillendirilir. Bu bağlamda, belirli bir alanı tercih eden topluluğun niceliği ve/veya niteliği sosyal ortamın ve dolayısıyla fiziki ortamın şekillenmesinde önemli bir unsurdur. İnsanlık tarihinin ilk aşamalarından bu yana belirlenmiş, tarif edilmiş ya da üretilmiş mekân sadece sığınma veya barınma ihtiyacını karşılamaktan öte giderek çeşitlenen birçok anlamı içinde barındırır. Bu anlamıyla, mekân sınırlanabilir fiziki bir alandan öte, tarihsel birikim ve toplumsal örgütlenme düzeyi ile sosyal ve politik tercihlerin bir izdüşümüdür.

Holosen dönemde Aşağı Garzan Havzası'ndaki en erken arkeolojik yerleşim yeri Neolitik döneme tarihlendirilen Sumaki Höyük yerleşmesidir. Bu yerleşim yeri plio-kuvaterner aşınım seviyesine konumlanmış olup, Garzan (Yanarsu) Çayının verimli alüvyon bölgesinden oldukça uzaktadır. Yerleşim yerinde yapılan arkeolojik kazı çalışmalarında ve açılan kazı alanın ke- sitlerinde birden çok sel-taşkın izi saptanmıştır. Dolayısıyla bu dönemde toplulukları gerek yerleşim stratejisi gerekse yerleşmeyi terk etme bağlamında belirgin bir şekilde fiziki ortamdaki farklılaşmalardan etkilenmiştir. Doğal çevre değişkenliği ve/ veya sel-taşkın gibi yıpratıcı dış etkiler nedeniyle bu yerleşim alanını iskân eden topluluklar farklı yaşam modelini seçmek zorunda kalmış ya da tamamen söz konusu alanı terk etmiştir.

Neolitik Dönem sonrasında (GÖ. 8000) İlk Tunç Çağ’a (GÖ.5000) kadar havza tamamen boş gibidir. Havzada yapılan üç kazı çalışmasında ve yüzey araştırmalarında GÖ.8000-5000 yılları arasını temsil eden Kalkolitik Dönem'e ait bir yerleşim yeri tespit edilememiştir. Gerek Sumaki Höyük Neolitik yerleşmesini kısmen örten sel-taşkın dolgusu; gerekse Gre Amer Höyük iTÇ tabakası üzerindeki kalın klüvyal dolgu ile Çemialo Sırt OTÇ tabakası üzerindeki kızılkahverengi renkli alüvyal dolgunun varlığı havzanın Kalkolitik Dönem'de güvenli bir alan olmadığını düşündürmektedir. Doğan'ın (2005) Bismil çevresinde yapmış olduğu araştırmada buna benzer bir durumun varlığı belirtmektedir. Neolitik ve Kalkolitik dönemlere ait yerleşimlerin Geç Holosen Dönem çökellerine gömülü olduğunu ve Neolitik Dönem'in başlangıcından itibaren sel baskınlarının varlığı bu çalışmada tespit edilmiştir. Ayrıca Aşağı Garzan Havzası'nın hemen dış doğu, bat, kuzey ve güney sınırlarında Kalkolitik dönem ait birçok yerleşmenin bulunmuş olmasına karşın; havzada hiç saptanmaması yerel fiziki etmenlerle açıklanabilir. Bununla birlikte bu dönem yerleşmelerin Bismil'deki yerleşmelere benzer bir şekilde oldukça kalın alüvyal veya klüvyal dolguların altında kalmış olması ihtimalini de dışarıda tutmamak gerekir. Aşağı Garzan Havzası asimetrik vadi yapısı, eğim özellikleri ile gevşek karakterdeki killi-çakıllı Şelmo Formasyonun geniş alanlara yayılması bu dolgunun diğer alanlara oranla daha kalın olabileceği de mümkündür. Rıdvan Köyü kar- 
şı kıyısında yaklaşık 5 metre kalınlığında klüvyal dolgu gevşek karakterdeki çakıllı akarsu taraçasını örtmektedir.

Neolitik dönem sonrasında ilk iskân İlk Tunç Çağ'dadır. Bu dönem yerleşmeleri suya yakın, verimli alanlarla çevrili ama tepelikler üzerine konumlanmıştır. Orta Tunç Dönemiyle birlikte yerleşim yerinde kısmen değişiklikler gözlemlenmiştir. OTÇ dönemi ile birlikte havzayı yaşam alanı olarak kullanan topluluklar, Garzan (Yanarsu) Çayı'ndan daha uzak mesafeleri, tarımsal açıdan daha az elverişli alanları da iskân yeri olarak kullanmaya başlamıştır. Hem Çemialo Sırt hem de Gre Amer Höyük kazı verileri bu dönemde taşkınların devam ettiğini dolayısıyla bazı grupların daha korunaklı alanları tercih ettiği ileri sürülebilir. Aşağı Garzan Havzası'nın yerleşim yoğunluğunun en fazla olduğu dönem Demir Çağı'dır. Bu Dönemde Kentalan Antiklinali'nin batı yamaçları hariç havzanın hemen hemen tamamında Demir Çağı kültür dolgusuna sahip yerleşim yeri görülmektedir. Bu yerleşmelerin bazıları daha önceki iTÇ-OTÇ döneminde olduğu gibi akarsu kenarlarında, yüksek tepelikler üzerinde ve verimli tarım alanlarının yaygın olduğu kesimlerdedir. Diğerleri ise korunaklı alanlardadır. ITÇ-OTÇ döneminin aksine çok yüksek ve çevreye hakim alanlar yerleşim yeri olarak tercih edildiği de gözlemlenmiştir. Önceki dönemlerde havzanın hiç kullanılmayan güney kesiminin de kullanılmaya başlanmıştır. Bu alandaki özellikle Şeyhosel Höyük yerleşmesinin Garzan (Yanarsu) Çayı'nın hemen kenarına konumlanması nedeniyle Demir Çağ Döneminde sel/taşkın gibi etmenlerin önceki dönemlere kıyasla daha az olduğu ya da etkilerin daha az yıpratıcı olduğu ileri sürülebilir.

Sonuç olarak, Neolitik Dönem ile sonraki zaman sürecinde Aşağı Garzan Havzası'nı kullanan topluluk ve/veya gruplar fiziki ortamın özelliklerine, sosyo-ekonomik tercihlerine ve dönemsel olarak kültürel dinamiklere göre ya da politik etkenler nedeniyle yerleşim stratejilerini belirlemiş veya Aşağı Garzan Havzası'nı tercih etmemişlerdir.

\section{Teşekkür ve Katkı Belirtme}

Bu çalışma, merhum hocam Prof. Dr. Telat Koç danışmanlığında ve özverili destekleriyle 2020 yılında Çanakkale Onsekiz Mart Üniversitesi Coğrafya Bölümünde tamamladığım “Aşağı Garzan Havzası'nda Jeomorfolojik Özelliklerin Arkeolojik Yerleşmelere Etkisi" başlıklı doktora tezinden çokça faydalanılmış, ayrıca Paris Nanterre Üniversitesi'nde 2019 yılında tamamladığım "Sumakı Höyük'ün Neolitik Mimari Yapıları ve Kültürel Peyzajı" başlıklı doktora tezinden de ihtiyaç duydukça yararlanılmıştır. Her iki çalışmada da desteğini eksik etmeyen merhum hocam Prof. Dr. Telat Koç ile Prof. Dr. Aslı Erim-Özdoğan ve Prof. Dr. Catherine Perles hocalarıma bir kez daha şükranlarımı sunarım. Ayrıca, makalemi büyük ölçüde geliştiren yapıcı yorumları için yayın kurulu üyelerine ve dergi hakemlerine de müteşekkirim.

\section{Kaynakça}

Algaze, G., Breuninger, R., Lightfoot, C., \& Rosenberg, M. (1991). The Tigris-Euphrates archaeological reconnaissance project: a preliminary report of the 1989-1990 seasons. Anatolica, XVII, 175240.

Altınlı, E. (1966). Doğu ve Güneydoğu Anadolu'nun jeolojisi. MTA Dergisi, 66, 35-77. https://dergi.mta.gov.tr/index.php?id=arsiv

Ardel, A. (1961). Güneydoğu Anadolu'da coğrafi müşahadeler. Türk Coğrafya Dergisi, 21, 140-148. https://dergipark.org.tr/tr/pub/ tcd/issue/21264/228287

Benedict, P. (1980). Güneydoğu Anadolu Yüzey Araştırması, İçinde H., Çambel \& R. J.Braidwood (eds.), istanbul ve Chicago üniversiteleri karma projesi Güneydoğu Anadolu tarihöncesi araştirmaları (ss.107-149). İstanbul Üniversitesi Yayınları No:2589.

Doğan, U. (2005). Holocene fluvial development of the Upper Tigris Valley (Southeastern Turkey) as documented by archaeological data. Quaternary International, 129, 75-86. https://doi.or$\mathrm{g} / 10.1016 /$ i.quaint.2004.04.008

Duman, T.Y., Olgun, Ş., Çan, T., Nefeslioğlu, H.A., Hamzaçebi, S., Elmacl, H., Durmaz, S., \& Çörekçioğlu, Ş. (2009). 1/25.000Ölçekli sayısal heyelan haritaları, M46-b1 paftası, Türkiye Jeoloji Veri Tabanı, Jeoloji Etütleri Dairesi Başkanlığı, Maden Tetkik ve Arama Genel Müdürlüğü, Ankara.

Erim-Özdoğan, A., \& Gündüzalp, S. (2018). Çemialo Sırt Batman-Beşiri-Yazıhan Köyü. Ilısu Barajı Projesi Kurtarma Kazıları (201-239. ss.). Batman Müzesi Yayını.

Erim-Özdoğan, A., \& Sarıaltun, S. (2011). Ilısu Baraj Alanı Garzan Vadisi ve Batman Çayı Çevresi Kültür Envanteri. İçinde N. Tuna \& O. Doonan (eds.), Ilısu ve Karkamış baraj gölleri altında kalacak arkeolojik ve kültür varlıklarını kurtarma projesi 2002 yılı çalışmaları, Cilt II (945-1146. ss.). ODTÜ-TAÇDAM.

Esentürk, Y. Ökse, A.T., \& Görmüş, A. (2007, Ekim 24). Anadolu Bronz Çağın'dan deprem izleri [Sözlü sunum]. International Earthquake Symposium Kocaeli 2007 Kitabı (758-762. ss.). Kocaeli Üniversitesi, Kocaeli, Türkiye.

Güney, B. (2014). Havza yönetim planları içerisinde sulak alanların yeri, kuş ve habitat direktifleriyle olan ilişkisi, TC. Orman ve Su İsleri Bakanlığı, Ankara, Türkiye. https://www.tarimorman.gov. tr/SYGM/Belgeler/TEZLER/Bihter\%20G\%C3\%9CNEY\%20(2).pdf

İmamoğlu, Ş.M., \& Çetin, E. (2007). Güneydoğu Anadolu Bölgesi ve yakın yöresinin depremselliği. D.Ü. Ziya Gökalp Eğitim Fakültesi Dergisi, 9, 93-103. https://dergipark.org.tr/tr/pub/zgefd/issue/47960/606809

Karadoğan, S. (2018). Garzan Havzasında jeomorfolojik peyzaj ve etkiler., Social Science Studies, 6(2), 237-271. DOI:10.18301/ rss.608

Kuzucuoğlu, C. (2002). Preliminary observation on the Tigris Valley terraces between Bismil and Batman. İçinde N. Tuna \& J. Velibeyoğlu (eds.), Salvage Project of the Archaeological Heritage of the IlIsu-Carchemish Dam Reservoirs Activities in 2000 (759-771. ss.). ODTÜ-TAÇDAM yayınları.

Laneri, N., D’Agostino, A., Schwartz, M., Valentini, S., \& Pappalardo, G. (2006). A preliminary report of the archaeological excavations at Hirbemerdon Tepe, southeastern Turkey. Anatolica, 32, 15388. DOI:10.2143/ANA.32.0.2012555

Matney, T., McGinnis, J., \& McDonald, H. (2002). Archaeological investigations at Ziyaret Tepe 2000 and 2001. Anatolica, 28, 4789. DOI:10.2143/ANA.28.0.2011761 
Ökse, A.T., Görmüş, A. \& Atay, E. (2009). Collapsed walls of a Middle Bronze Age building at Salat Tepe (Diyarbakır): evidence for an earthquake? İçinde Ç. Özkan Aygün (ed.), SOMA 2007 Proceedings of the XI Symposium on Mediterranean Archaeology (277283. ss.), BAR International Series 1900.

Parker, B. (2001). The mechanics of empire, the northern frontier of Assyria as a case study in imperial dynamics. Institute for Asian and African Studies, University of Helsinki.

Parker, B., \& Swartz-Dodd, L. (2005). The Upper Tigris archaeological research project, a preliminary report from the 2002 field season. Anatolica, 31, 69- 110. DOI: https://doi.org/10.2307/3643077

Polat, i. (2018). Yanarsu (Garzan) Çayı aşağı havzası (Siirt / Kurtalan) jeomorfolojisi. (Yayın No. 515189) [Yükseklisans tezi, Fırat Üniversitesi]. https://tez.yok.gov.tr/UlusalTezMerkezi/tezSorguSonucYeni.jsp

Pulman, G., \& Blaylock, S. (2018). Garzan Vadisi'nde üç binyıl: Batman, Gre Amer Höyük kurtarma kazıları, Ilısu Barajı Projesi Kurtarma Kazıları (111-162. ss.), Batman Müzesi.

Sarıaltun, S. (2019). The Neolithic architectural structures and cultural landscape of Sumaki Höyük (Publication No. PA100166) [Doctoral dissertation, Paris Nanterre University]. https://www. theses.fr/2019PA100166

Sarıaltun, S. (2020). Aşağı Garzan Havzası'nda jeomorfolojik özelliklerin arkeolojik yerleşmelere etkisi (Yayın No. 644472) [Doktora tezi, Çanakkale Onsekiz Mart Üniversitesi]. https://tez.yok.gov. tr/UlusalTezMerkezi/tezSorguSonucYeni.jsp

Sunkar, M., \& Polat, í. (2018 Mayıs 25). Yanarsu (Garzan) Çayı taraçalarının jeomorfolojik özellikleri (Kurtalan / Siirt) [Sözlü sunum]. VIII. Türkiye Kuvaterner Sempozyumu, ITÜ Avrasya Yer Bilimleri Enstitüsü, İstanbul, Türkiye.

Sunkar M., \& Tanbul S. (2012) Iluh Deresi (Batman) Havzası'nın Jeomorfolojisi. Coğrafya Dergisi, 24, 38-60. https://dergipark.org. $\underline{\mathrm{tr} / \mathrm{tr} / \text { pub/iucografya/issue/25069/264616 }}$

Şenel, M. (2007). 1:100.000 ölçekli Türkiye jeoloji haritaları, Mardin-M46 Paftası. No: 69. Maden Tetkik ve Arama Genel Müdürlüğü, Jeoloji Etütleri Dairesi, Ankara.

Şenel, M. (2008). 1:100.000 ölçekli Türkiye jeoloji haritaları, Mardin-M47 paftası. No: 66. Maden Tetkik ve Arama Genel Müdürlüğü, Jeoloji Etütleri Dairesi, Ankara.

Şimşek, R. (1979). Yukarı Dicle Havzası hidrojeolojik etüt raporu, 1054. DSi Genel Müdürlüğü

Tolun, N. (1962). Diyarbakır sheet:500.000 scale, explanatory text of the geological map of Turkey. MTA.

Yeşilova, Ç. (2012). Baykan-Kurtalan-Şirvan (Siirt) arasındaki tuz içeren birimlerin stratigrafik-sedimantolojisi incelemesi ve ekonomik önemi (Yayın No. 309825) [Doktora tezi, Yüzüncü Yıl Üniversitesi]. https://tez.yok.gov.tr/UlusalTezMerkezi/tezSorguSonucYeni.jsp

Yeşilova, Ç., \& Helvacı, C. (2011). Batman-Siirt kuzeyi stratigrafisi ve sedimantolojisi, Türkiye, TPJD Bülteni, 23(2), 7-50. http://www. tpjid.org.tr/images/bultenler/pdf/aralik2011.pdf

Yıldırım, A. \& Karadoğan, S. (2005 Eylül). Raman-Gercüş antiklinalleri arasında Dicle Vadisinin jeomorfolojisi [Sözlü sunum]. Ulusal Coğrafya Kongresi 2005 Bildiri Kitabı (421-433. ss.). Türk Coğrafya Kurumu, İstanbul, Türkiye.

Yılmaz, E. \& Duran, O. (1997). Güneydoğu Anadolu Bölgesi otokton ve allokton birimlerin stratigrafi sözlüğü. TPAO Araşttrma Merkezi, Eğitim Yayınları No:31.
MTA yerbilimleri harita görüntüleyici ve çizim editörü: http://verbilimleri.mta.gov.tr/anasayfa.aspx (Erişim tarihi: 25.05.2021) 